$(200)$

R290

no $95-613$
U.S. DEPARTMENT OF THE INTERIOR
U.S. GEOLOGICAL SURVEY

Fi w

FEB 12 i 1950

OSTI

\title{
Characterization of Quaternary and Suspected Quaternary Faults, Amargosa area, Nevada and California
}

by

R. Ernest Anderson, Anthony J. Crone, Michael N. Machette,

Lee-Ann Bradley, and Sharon F. DiehI

\section{Open-File Report 95-613}

This report is preliminary and has not been reviewed for conformity with U.S. Geological Survey editorial standards (or with the North American Stratigraphic Code). Any use of trade, product, or firm names is for descriptive purposes only and does not imply endorsement by the U.S. Government.

Box 25046, MS 966

Denver, Colorado 80225

U.S.A.

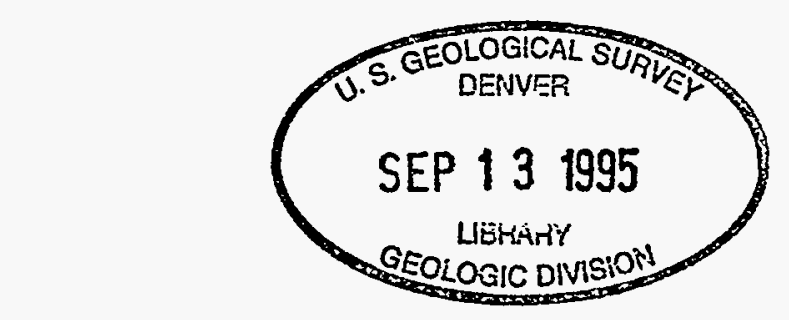

1995 


\title{
United.States Department of the Interior
}

\author{
U.S. GEOLOGICAL SURVEY \\ Box 25046 M.S. 902 \\ Denver Federal Center \\ Denver, Colorado 80225
}

IN REPLY REFER TO.

September 12, 1995

\section{MEMORANDUM}

To: Books and Open-File Reports Section

From: $\quad$ Chief, Office of Scientific Publications

Subject: New USGS open-file report

The following report was authorized by Diane N. Jones for the Director on 08/17/95 for release as an open file report.

Project Number: $995063515 \quad$ (D950620)

TITLE: Characterization of Quaternary and suspected Quaternary faults, Amargosa area, Nevada and California

AUTHOR: Anderson, R. Ernest Crone, Anthony J. Machette, Michael N. Bradley, Lee-Ann Diehl, Sharon F.

CONTENTS: 50 pages, 5 oversize sheets (included with text)

\section{DEPOSITORIES}

(NC) USGS Library, Room 4A100, 12201 Sunrise Valley Dr., Reston, VA 22092

$\checkmark$ (Da) USGS Library, Building 20, Room C2002, Denver Federal Center

(Mail address: Mail Stop 914, Box 25046, Federal Center, Denver, CO 80225)

(M) USGS Library, 345 Middlefield Rd., Menlo Park, CA 94025

(U) USGS-ESIC, 2222 W. 2300 S., 2nd Floor., Salt Lake City, UT 84119

Nevada Bureau of Mines \& Geology, University of Nevada-Reno, Reno, NV 89557-0088

Mines \& Geology Library, Dept. of Conservation, 801 K Street, MS 14-34, Sacramento, CA 95814-3532

California Division of Mines \& Geology, State Office Building, 107 South Broadway, Los Angeles, CA 90012

California Division of Mines \& Geology, 185 Berry Street, Suite 3600, San Francisco, CA 94107

\begin{tabular}{|l|c|l|}
\hline PRICE: & ORIGINATING OFFICE & Release date: SEP 1995 \\
\hline Fiche \$ & Name: BCTR (Stop 902), Denver, CO & Area: NV CA \\
\hline Paper \$ & Telephone: FTS 776-5456 & OFR No. OF95-613 \\
\hline
\end{tabular}




\section{CONTENTS}

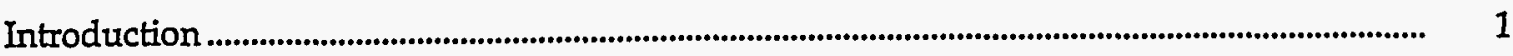

Pahrump-Stewart Valley fault zone (PSV) ........................................................................................... 8

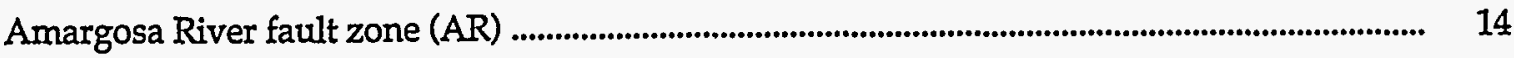

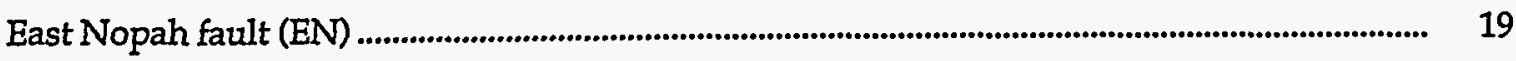

Ash Meadows fault zone (AM) ............................................................................................................... 25

Rock Valley fault zone (RV), southwestern extension ...................................................................... 33

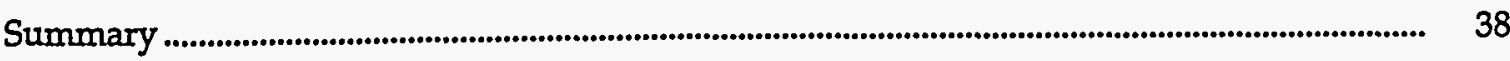

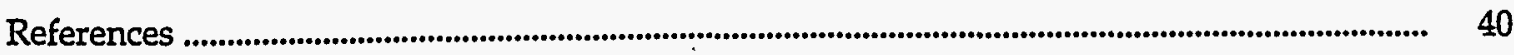

Appendix A: Definitions ................................................................................................................... A-1

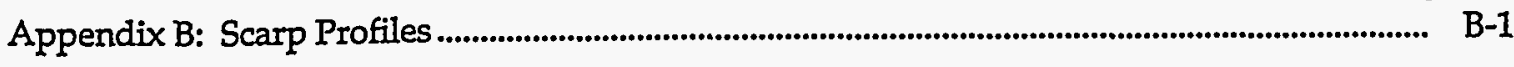

Profile of the Pahrump-Stewart Valley fault zone ............................................................. B-2

Profile of the Amargosa River fault zone.................................................................................. B-2

Profiles of the East Nopah fault ............................................................................................ B-2

Profiles of the Ash Meadows fault zone ................................................................................... B-4

Profiles of the Rock Valley fault zone, southwestern extension .......................................... B-7

\section{ILLUSTRATIONS}

FIGURE 1. Map of regional faults studied ................................................................................................ 2

2. Definitions of scarp parameters ........................................................................................ 5

3. Scarp-height-slope-angle values for selected single-event scarps in Utah................. 5

4. Maps of faults western Great Basin and structural blocks Walker Lane belt ............... 6

5. Map of Pahrump-Stewart Valley fault zone ........................................................................... 9

6. Profile across Pahrump-Stewart Valley fault zone ............................................................... 12

7. Scarp-height-slope-angle value for Pahrump-Stewart Valley fault zone .................... 13 
FIGURE 8. Map of Amargosa River fault zone ................................................................................... 16

9. Scarp-height-slope-angle values for Amargosa River fault zone ................................. 18

10. Map of East Nopah fault ................................................................................................................ 20

11. Profile across typical scarp on East Nopah fault ............................................................. 21

12. Scarp-height-slope-angle values for East Nopah fault .................................................. 23

13. Map of Ash Meadows fault zone .................................................................................... 26

14. Scarp-height-slope-angle values for Ash Meadows fault zone .................................. 29

15. Map of part of Ash Meadows fault zone .................................................................................... 31

16. Map of part of Rock Valley fault zone near Nevada Highway 29 ................................... 34

17. Map of part of Rock Valley fault zone near Skeleton Hills ................................................ 35

18. Scarp-height—slope-angle values for Rock Valley fault zone ........................................... 37

\section{TABLES}

TABLE 1. Fault data for selected regional faults ............................................................................ 3

2. Time intervals for the Quaternary ............................................................................................. 4

3. Scarp-profile data for Amargosa River fault zone (AR) ....................................................... 17

4. Scarp-profile data for East Nopah fault (EN) ...................................................................... 22

5. Scarp-profile data for Ash Meadows fault zone (AM) ..................................................... 28

6. Scarp-profile data for southwestern extension, Rock Valley fault zone (RV) ...................36

\section{DISCLAIMER}

This report was prepared as an account of work sponsored by an agency of the United States Government. Neither the United States Government nor any agency thereof, nor any of their employees, makes any warranty, express or implied, or assumes any legal liability or responsibility for the accuracy, completeness, or usefulness of any information, apparatus, product, or process disclosed, or represents that its use would not infringe privately owned rights. Reference herein to any specific commercial product, process, or service by trade name, trademark, manufacturer, or otherwise does not necessarily constitute or imply its endorsement, recommendation, or favoring by the United States Government or any agency thereof. The views and opinions of authors expressed herein do not necessarily state or reflect those of the United States Government or any agency thereof. 


\title{
Characterization of Quaternary and suspected Quaternary faults,
}

\author{
Amargosa area, Nevada and California
}

\author{
By R. Ernest Anderson, Anthony J. Crone, Michael N. Machette, \\ Lee-Ann Bradley, and Sharon F. Diehl
}

\section{INTRODUCTION}

This report presents the results of geologic studies that help define the Quaternary history of selected faults in the region around Yucca Mountain, Nevada. These results are relevant to the seismic-design basis of a potential nuclear waste repository at Yucca Mountain. The relevancy is based, in part, on a need for additional geologic data that became apparent in ongoing studies by S. Pezzopane (written commun., 1995) that resulted in the identification of 51 relevant and potentially relevant (see appendix $A$ for definitions) individual and compound faults and fault zones in the 100-km-radius region around the Yucca Mountain site. These structures were divided into local and regional categories by Pezzopane (1995); this report deals with selected regional structures. In this introduction, we outline the scope and strategy of the studies and the tectonic environment of the studied structures.

Geologic data used in the characterization of the regional faults and fault zones as relevant or potentially relevant seismic sources (Pezzopane, 1995, written commun., 1995) includes age (Quaternary) and displacement information, maximum fault lengths, and minimum distances between the fault and the Yucca Mountain site. Most of these data are found in Piety (1994) who compiled the data from maps, literature reviews, and reconnaissance investigations of faults. For many of the regional faults, no paleoseismic field studies had been conducted at the time of Piety's study, and age and displacement data were sparse to nonexistent. In November 1994, the Branch of Earthquake and Landslide Hazards entered into two memoranda of agreement with the Yucca Mountain Project Branch to conduct field reconnaissance, analysis, and interpretation of six relevant and six potentially relevant regional faults whose approximate traces are shown on figure 1. Data on these faults taken from Pezzopane (1995) are given in table 1. Because there were two separate memoranda of agreement, we prepared two separate reports, one for each project. This report describes the results of study of the faults in the Pahrump-Stewart Valley, Amargosa River, and Ash Meadows areas. The results of studies of the other faults are described in a companion report (Anderson and others, 1995). Although not on the list of relevant or potentially relevant faults (Pezzopane, written commun., 1995), we include the results of a cursory study of Quaternary fault scarps along the east base of the Nopah Range southwest of Pahrump, Nevada. Also, because the Rock Valley fault zone, a relevant source located southeast of Yucca Mountain, extends southwestward into the Amargosa Desert where we were working, we made a cursory examination of scarps that mark its apparent southwesternmost extent and report the results here.

A four-phase strategy was implemented for both projects. It consisted first of a 4-day field orientation that utilized the expertise of geologists and paleoseismologists with past and current research experience in 


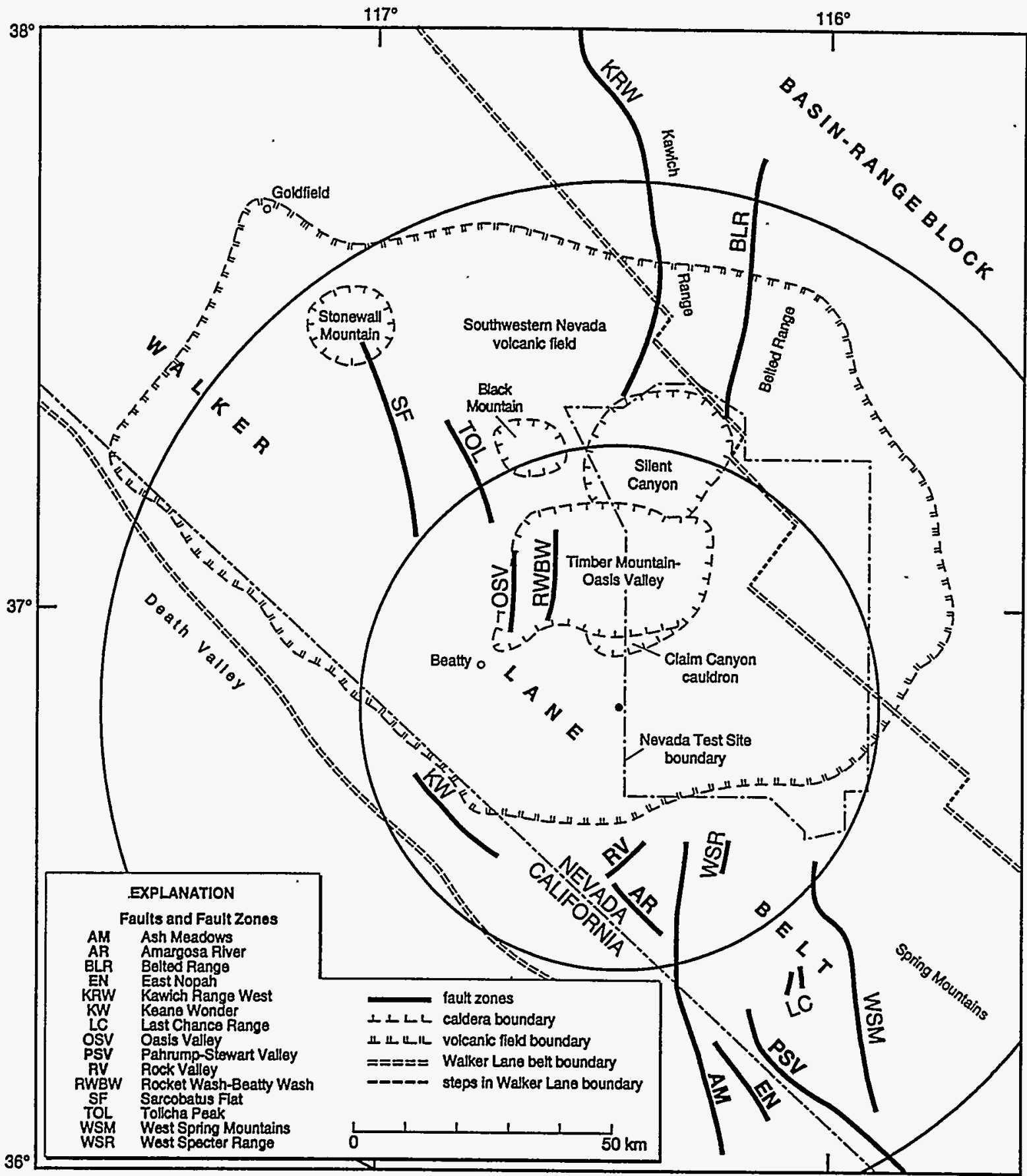

Flaure 1. Map showing generalized traces of the regional faults studied under the two Memoranda of Agreement between the Yucca Mountain Project Branch and Branch of Earthquake and Landslide Hazards, U.S.G.S. Abbreviations in bold type identify faults described in this report, abbreviations in regular type identify faults described in a companion report (Anderson and others, 1995). Selected regional geologic features include Walker Lane belt, boundaries of the southern Nevada volcanic field, and some calderas within that field (modified from Carr, 1988). Dot at center of 50- and 100-km-radius circles marks location of proposed repository site. Most fault traces and abbreviations are from Pezzopane (1995). 
TABLE 1. Fault data for selected regional faults from Pezzopane (1995, written commun., 1995).

[These data pre-date our results. They are organized according to distance from Yucca Mountain (YM). Fault names in bold type indicate structures described in this report; others are described in a companion report (Anderson and others, 1995).]

\begin{tabular}{|c|c|c|c|c|}
\hline $\begin{array}{c}\text { Minimum } \\
\text { distance to YM } \\
(\mathrm{km})\end{array}$ & $\begin{array}{c}\text { Fault name } \\
\text { and } \\
\text { abbreviation }\end{array}$ & $\begin{array}{c}\text { Relevant } \\
\text { fault" }\end{array}$ & $\begin{array}{c}\text { Documented } \\
\text { Quaternary } \\
\text { displacement"* }\end{array}$ & $\begin{array}{c}\text { Maximum } \\
\text { fault length } \\
(\mathrm{km})\end{array}$ \\
\hline 19 & $\begin{array}{c}\text { Rocket Wash-Beatty Wash } \\
\text { RWBW }\end{array}$ & yes? & yes? & 17 \\
\hline 24 & $\begin{array}{l}\text { Oasis Valley } \\
\text { OSV }\end{array}$ & yes? & yes? & 20 \\
\hline 27 & $\begin{array}{l}\text { Rock Valley } \\
\text { RV }\end{array}$ & yes & yes & 65 \\
\hline 34 & $\begin{array}{c}\text { Ash Meadows } \\
\text { AM }\end{array}$ & yes & yes & 60 \\
\hline 40 & $\begin{array}{c}\text { Amargosa River } \\
\text { AR }\end{array}$ & yes & yes & 15 \\
\hline 42 & $\begin{array}{l}\text { Tolicha Peak } \\
\text { TOL }\end{array}$ & yes? & yes? & 22 \\
\hline 43 & $\begin{array}{c}\text { Keane Wonder } \\
\text { KW }\end{array}$ & yes? & yes? & 25 \\
\hline 52 & $\begin{array}{l}\text { Sarcobatus Flat } \\
\text { SF }\end{array}$ & yes & yes? & $51^{\circ}$ \\
\hline 53 & $\begin{array}{l}\text { West Spring Mountain } \\
\text { WSM }\end{array}$ & yes & yes & 60 \\
\hline 55 & $\begin{array}{c}\text { Belted Range } \\
\text { BLR }\end{array}$ & yes & yes & 54 \\
\hline 57 & $\begin{array}{l}\text { Kawich Range West } \\
\text { KRW }\end{array}$ & yes? & yes? & 84 \\
\hline 70 & $\begin{array}{c}\text { Pahrump-Stewart Valley } \\
\text { PSV }\end{array}$ & yes & yes & 70 \\
\hline
\end{tabular}

* yes indicates relevant; yes? indicates potentially relevant

** yes indicates documented Quaternary displacement or compelling evidence for displacement potential such as seismicity; yes? indicates suspected Quaternary displacement

the region including J. Whitney, S. Pezzopane, J. Yount, C. Menges, L. Anderson, and D. Donovan. The purpose was to familiarize project personnel with the geography, access, and geology of the region, including a visit to Yucca Mountain, several faults, and trench sites. The second phase consisted of office and lab study of aerial photographs and maps which, for some areas, included unpublished Quaternary fault maps provided by $M$. Reheis and L. Anderson. The third phase consisted mainly of field study of the faults shown by bold type on figure 1 . Each of the faults was studied by a field team led by A. J. Crone (PahrumpStewart Valley fault zone-PSV, East Nopah fault-EN, and Ash Meadows fault zone-AM) and M.N. Machette (Amargosa River fault zone-AR, and Rock Valley fault zone-RV). The scope of these field studies, as outlined in the memorandum of agreement, included: (1) determining the geomorphic character that defines the subject faults capability, (2) determining the length of the fault with such capability, and (3) estimating the time of the most recent surface offset and, where indicated, evidence of recurrent offsets 
TABLE 2. Terminology of time intervals for the Quaternary Period used in this report and approximate dates of time boundaries (modified from Morrison, 1991, and Izett and Obradovich, 1994).

\begin{tabular}{ll}
\hline Subdivision & Time Span \\
\hline Holocene & present-10 ka \\
latest Pleistocene & $10 \mathrm{ka} \sim 28 \mathrm{ka}$ \\
late Pleistocene & $10 \mathrm{ka} \sim 128 \mathrm{ka}$ \\
middle Pleistocene & $\sim 128 \mathrm{ka}-770 \mathrm{ka}$ \\
early Pleistocene & $770 \mathrm{ka}-1650 \mathrm{ka}$ \\
Pleistocene & $10 \mathrm{ka}-1650 \mathrm{ka}$ \\
late Quaternary & present $\sim 128 \mathrm{ka}$ \\
Quaternary & present-1650 ka \\
\hline
\end{tabular}

in the Quaternary. The final phase consisted of a 5-day field review (with the team leaders, R.E. Anderson, Principal Investigator, and others) by M. Reheis and A. Nelson. This field review served as a formal review of the field-data package pertaining to these studies.

In this report we use terminology for several subdivisions of the Quaternary period. Although the terminology for most subdivisions is widely agreed upon by earth scientists, the accepted age of these subdivisions has varied through the years. In this report, we generally follow the subdivisions as defined by Morrison (1991), but we use a revised age of $770 \mathrm{ka}$ for the early Pleistocene-middle Pleistocene boundary (Izett and Obradovich, 1994) and use an informal latest Pleistocene subdivision. The subdivisions we use are shown in table 2.

We use the morphology of fault scarps on alluvium to characterize the history of surface faulting. The morphology is defined by topographic profiles measured across the scarp. Parameters derived from the profiles and used in this report to characterize the scarps are defined on figure 2. The parameters are either taken directly from measurements recorded in the field (scarp-slope angle) or derived from the profile (scarp height, surface offset).

Profiles were made by measuring a sequence of short intervals (typically $\leq 4.5 \mathrm{~m}$ ) of slope distance and slope angle along the ground surface, perpendicular to the local strike of the scarp. The profiles are long enough to include intervals of the surfaces above and below the scarp that are judged to be unaffected by scarp modification processes, such as erosion and deposition. To minimize the influence of local topographic irregularities, several measurements of the scarp-slope angle may be made adjacent to the line of profile.

Scarp profiles provide information for estimating the time of surface-faulting events based on the intuitively obvious observation that with increasing age a scarp profile becomes more rounded and the slope of the scarp face becomes less steep. A variety of methods of analyzing the form of scarp profiles have been developed, and most of these methods model the profile as a solution to the diffusion equation (Nash, 1980; Hanks and others, 1984). In most cases, the profile data in this study are very limited, and we have not attempted to model the scarps using the diffusion model. Instead we graph several parameters of our profiles as a convenient visual means of characterizing the relative age based on the morphology of the scarps. For this we use the relation of Bucknam and Anderson (1979), who showed that at a given scarp height, the scarp-slope angle decreases with increasing age. They also found that, for a scarp of a given age, there is a linear relation between scarp-slope angle and the logarithm of the scarp height. Figure 3 shows this relation for 3 scarps in western Utah. The ages of the scarps are about $15 \mathrm{ka}$ for the Lake Bonneville 


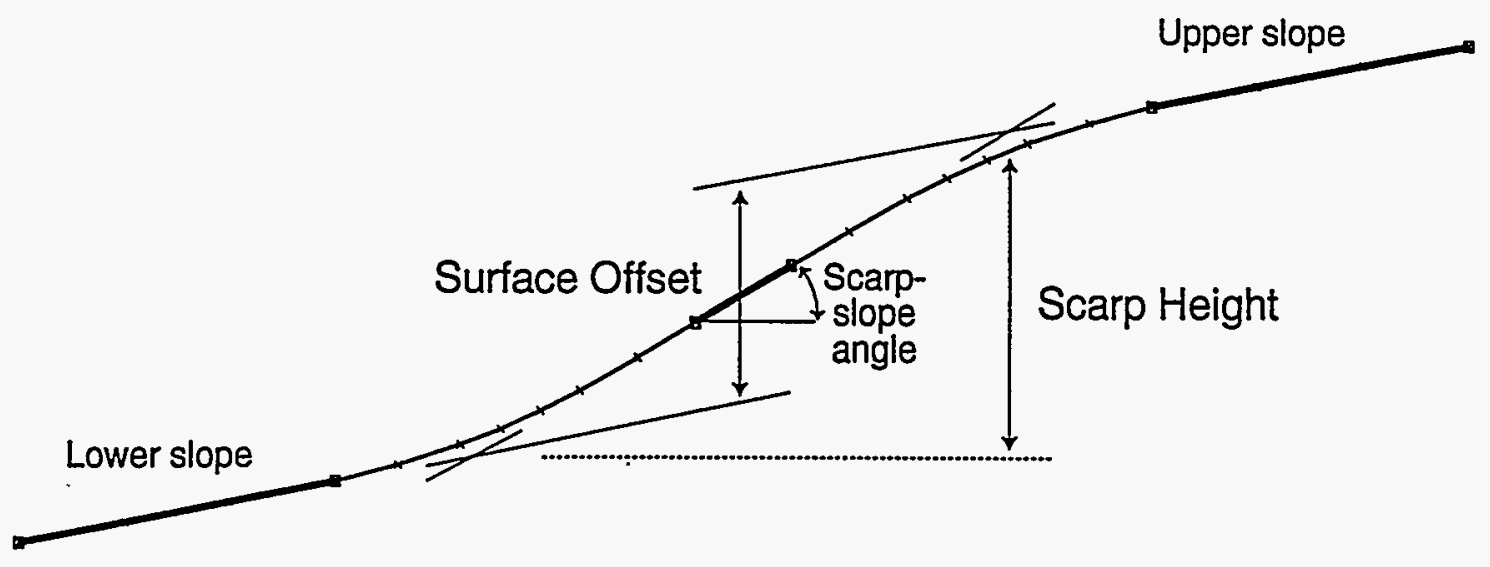

FIGURE 2. Definitions of scarp parameters. Upper and lower slope are intervals of the scarp profile that represent the prefaulting surfaces above and below the scarp. Scarp-slope angle is the steepest interval on the scarp face. Surface offset is the vertical distance between the projections of the upper and lower surfaces measured mid-way between the intersections of the steepest interval of the scarp face and the projections of the upper and lower surfaces; scarp height is the vertical relief between those intersections.

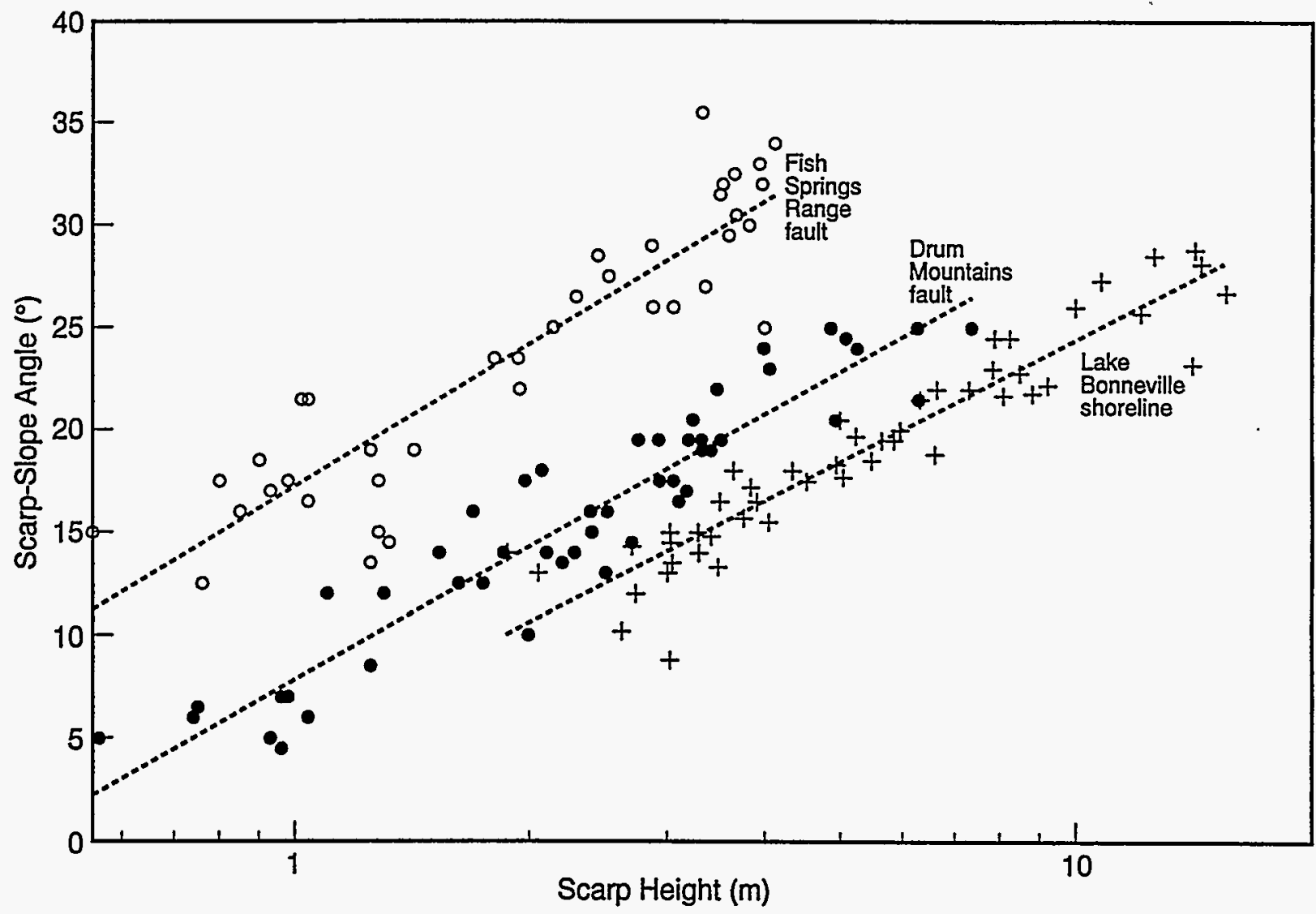

FIGUAE 3. Scarp-slope angle versus log scarp-height data for single-event scarps in western Utah. The figure illustrates the resolution and variability of scarp-morphology data. Dotted lines are linear regressions to each of the sets of data. Open circles, fault scarp of Fish Springs Range (about 2 ka; Bucknam and others, 1989); solid circles, fault scarp of Drum Mountains (about $10 \mathrm{ka}$; Crone, 1983); crosses, shoreline scarp of Lake Bonneville (about 15 ka; Machette, 1989). 
shoreline (Machette, 1989), about $10 \mathrm{ka}$ for the Drum Mountains fault (Crone, 1983), and about $2 \mathrm{ka}$ for the Fish Springs Range fault (Bucknam and others, 1989). The data points are shown on figure 3 to illustrate the resolution and variability expected from profile data taken from late Pleistocene and Holocene scarps that represent a single scarp-forming event. In this report we use plots of scarp-slope angle versus log scarp height to qualitatively compare the data from this study to the approximately $10 \mathrm{ka}$ fault scarp of the Drum Mountains, the approximately $15 \mathrm{ka}$ shoreline scarp of Lake Bonneville in western Utah, and the approximately $100 \mathrm{ka}$ Santa Rita scarp in southern Arizona (Pearthree and Calvo, 1987).

To assess the Quaternary history of most of the faults, we estimated the age of most recent displacement and placed some boundaries (constraints) on fault slip rates. We did this by estimating the age of the offset surface based on its surface morphology and degree of soil development.

The faults discussed in this report are located within the Walker Lane structural belt of the Basin and Range. Mountain ranges in this belt are characterized by varied shapes and trends (figs. 1, 4A, 4B) resulting from an irregular mixture of (1) strike-slip faults, (2) regional sections of quasi-coherent internal structure, (3) basin-range faults, (4) oroflexural folds, and (5) areas of large-scale extension, detachment faults, and metamorphic core complexes (Stewart, 1988). The Walker Lane belt is divided into regional structural sections each of which has undergone internal deformation independent of adjacent sections, with adjustments for intersectional strain contrasts most likely made at section boundaries (Stewart, 1988, Carr, 1988). Individual strike-slip faults do not extend along the length of the Walker Lane belt or even from one section to another.

Although the Quaternary faults described in this report, all fall within the Walker Lane.belt, they are located in a structurally complex part of the belt characterized by boundaries and intersections between four of the structural sections (fig. 4B) recognized by Stewart (1988). Accordingly, the faults include known or inferred right-slip (PSV, AR, EN), left-slip (RV), and normal (AM) faults. The way in which these faults interact or interconnect with one another is of potential importance to hazards and ground-water assessments at Yucca Mountain.
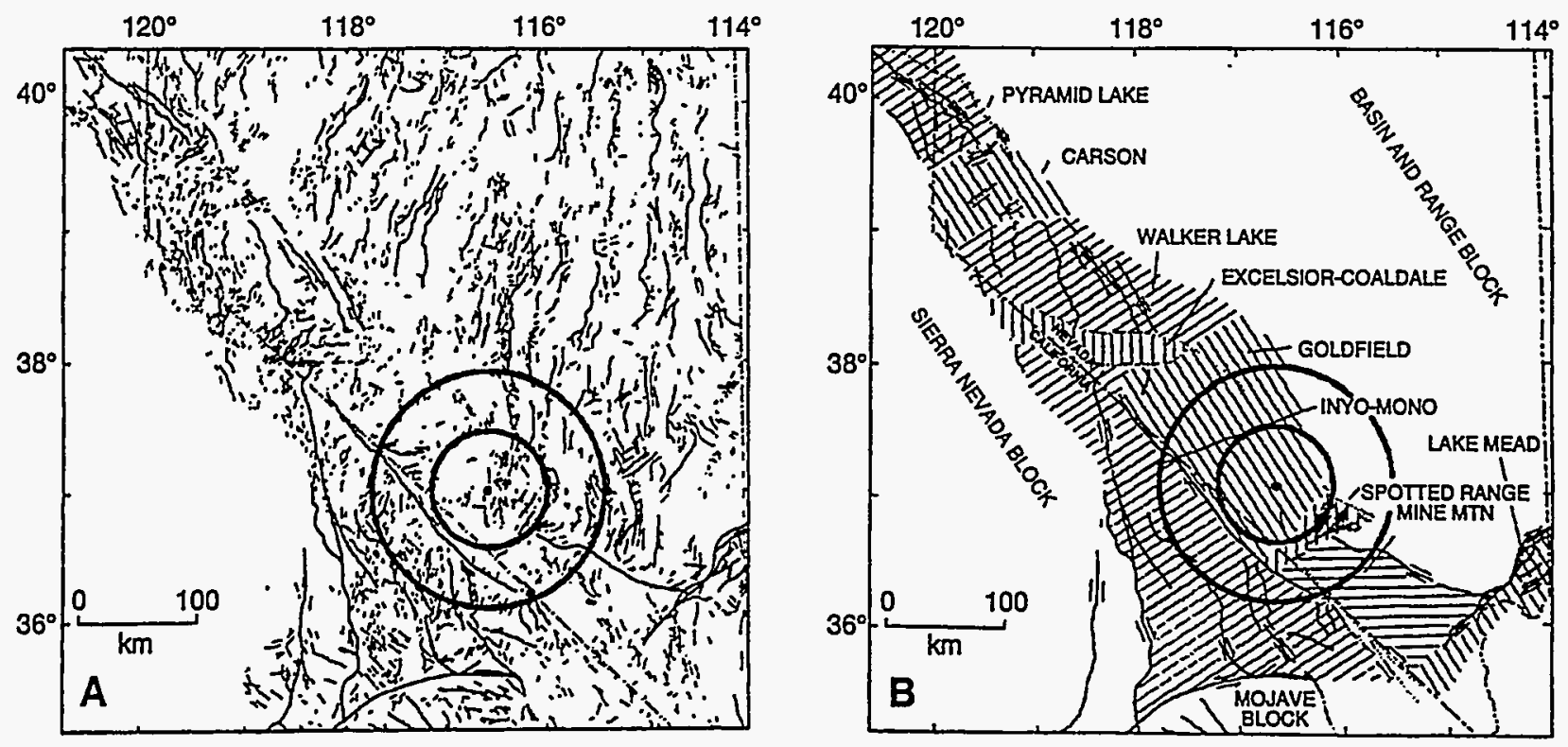

Figure 4. A, Map showing the Yucca Mountain site (dot at center of $50-$ and $100-\mathrm{km}$ circles) relative to late Cenozoic faults in the western Great Basin (modified from Stewart, 1988). B, Same area as in A showing selected major faults and regional structural blocks (cross ruled) of the Walker Lane belt (from Stewart, 1988). 
The surface trace of each fault is located mainly in basin-fill sediment that lack deep incision or strong tilting that might otherwise provide access to detailed knowledge of their stratigraphy and structure. Lacking this knowledge, the tasks of assessing fault interaction and interconnectedness are extremely difficult ones that cannot be accomplished by surface studies of the kind reported here. Nevertheless, information we provide on related matters of fault length and surface-trace continuity help address those tasks.

Structural development of the Yucca Mountain region during the Tertiary was strongly influenced by volcano-tectonic processes related to formation of the southwest Nevada volcanic field (Byers and others, 1976) from which hundreds of cubic kilometers of silicic tuff and lava were erupted (Carr, 1984). All the faults reported on here are located outside the boundary of the southwest Nevada volcanic field and associated calderas (fig. 1) and probably have no volcano-tectonic component to their history.

We describe each fault or fault zone separately using the abbreviations of Pezzopane (1995). The descriptions are grouped according to faulting style. First we describe the strike-slip faults that are reported to be part of the right-slip Walker Lane-the Pahrump-Stewart Valley and the Amargosa River and, as we have determined, the East Nopah. Second, we describe the Ash Meadows fault zone of probable normal displacement. Finally, we describe our cursory observations of reported left-slip displacement on the southwestern part of the Rock Valley fault zone. The descriptions are organized to facilitate the integration of our results into future updates of regional compilations such as that of Piety (1994). 


\section{PAHRUMP-STEWART VALLEY FAULT ZONE (PSV)}

SUMMARY: The Pahrump-Stewart Valley fault zone (PSV) trends about N. $45^{\circ} \mathrm{W}$. along the axial part of Pahrump and Stewart Valleys in Nye County, Nevada, and Inyo County, California. The PSV has been estimated to be as much as $130 \mathrm{~km}$ long, but compelling evidence of late Quaternary deformation is present only along about 18.5-km-long section between the southeastern end of Stewart playa and about $6 \mathrm{~km}$ south of the town of Pahrump. Farther south and southeast of Pahrump, the PSV is characterized by sinuous, 8- to 15-m-high escarpments in Quaternary or Tertiary deposits, and by vegetation lineaments, fissures, and patches of cemented fan deposits in the medial part of the valley. No significant late or middle Pleistocene movement has occurred on the dissected, greatly eroded escarpments.

At the northwestern end of the PSV, we found no evidence of a connection between Quaternary faulting in Stewart Valley and faulting along the Ash Meadows or Amargosa River fault zones. Unfaulted Quaternary deposits at least several hundred thousand years old cross the mapped trace of the Stewart Valley fault in northern Stewart Valley. A 15- to 20-km-long gap separates Quaternary scarps and lineaments along the PSV from similar features in the Amargosa Desert.

The southeastern end of the PSV is difficult to define. High-altitude imagery suggests that Quaternary deformation may extend as far south as Black Butte, whereas gravity and magnetotelluric data suggest that the PSV may continue to near Stateline Pass in southeastern Mesquite Valley.

Quaternary slip is inferred to be right-lateral mainly because this is the sense of slip indicated by offset Paleozoic and Precambrian rocks, which are offset $16-19 \mathrm{~km}$. Most of this offset probably occurred during the Mesozoic and early Cenozoic. The amount of Quaternary lateral slip on the PSV is unknown. Scarps are rare along the PSV, and those that are present are formed on silty playa deposits. The morphology of a small single-event(?) scarp suggests that the most recent faulting event may be early or middle Holocene in age.

Most of the 8- to 15-m-high escarpments in southern Pahrump Valley are probably fault-line scarps that mark the general location of underlying faults. The relief of these escarpments provides a first-order estimate of a long-term vertical slip rate. Sediment in the escarpments is thought to be Tertiary or early Pleistocene in age. If these sediments are early Pleistocene and vertically displaced $15 \mathrm{~m}$, then the vertical slip rate is about $0.02 \mathrm{~mm} / \mathrm{yr}$. If the sediment is late Tertiary (latest Pliocene), then the vertical slip rate is $0.009 \mathrm{~mm} / \mathrm{yr}$. The limited expression of the PSV in Quaternary deposits is evidence that the fault zone's long-term Quaternary slip rate is low.

LOCATION: The PSV extends along the axial part of Pahrump and Stewart Valleys in Nye County, Nevada, and Inyo County, California. The fault zone is essentially coincident with the California-Nevada state boundary and, therefore, has been referred to as the "Stateline" fault system by some investigators (see Hoffard, 1991). Scarps and lineaments mapped as part of the PSV (Hoffard, 1991) are as close as 3-5 km from the town of Pahrump (fig. 5), which is the largest settlement in the region.

ORIENTATION: about N. $45^{\circ} \mathrm{W}$. 


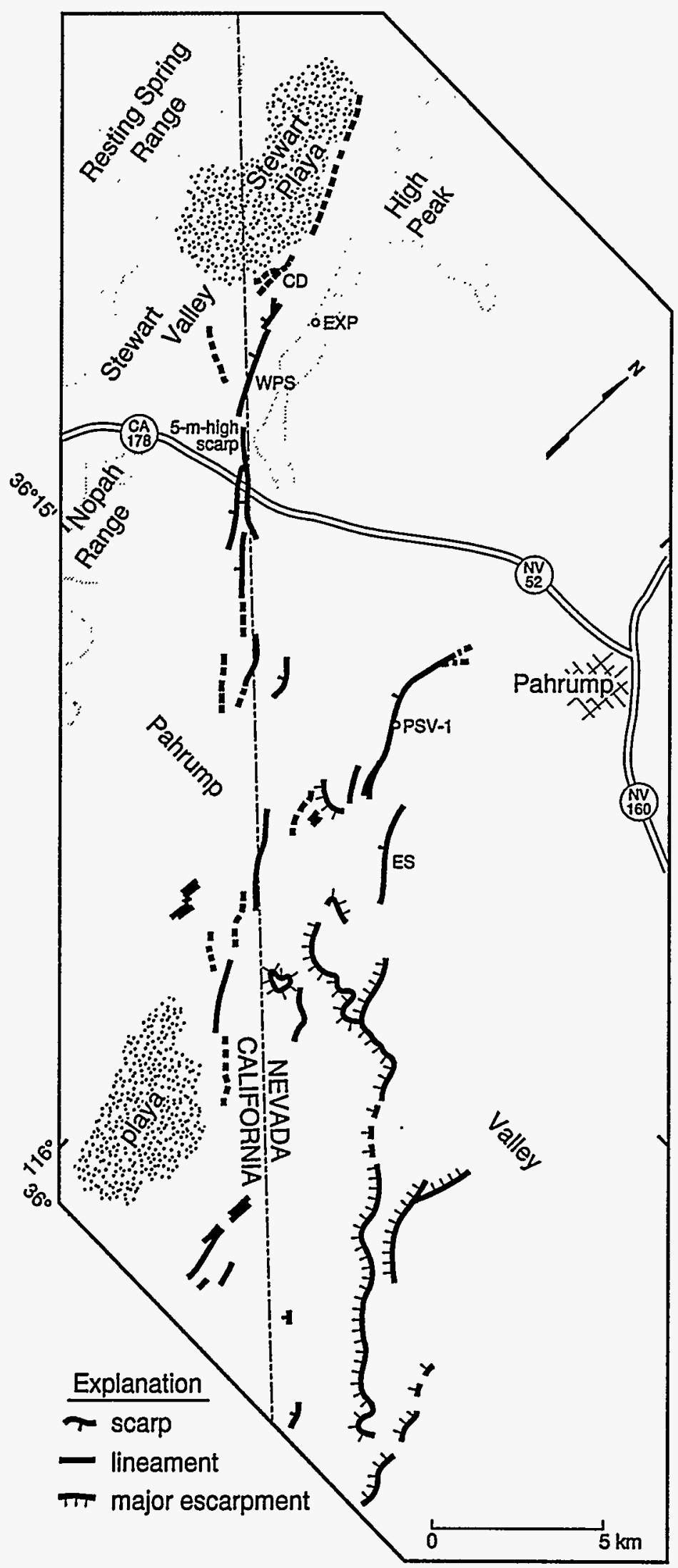

Figure 5. Map showing selected features of Pahrump-Stewart Valley fault zone (PSV) (after Hoffard, 1991). Locations discussed in the text include: $C D$, closed depression; ES, eroded scarp; EXP, exposure of Stewart Valley fault; PSV-1, profile site PSV-1; and WPS, warped playa sediment. Extent of mostly continuous bedrock shown by halftone fill. The most prominent scarps on late Quaternary deposits are in the Stewart Valley area, but the biggest escarpments associated with faulting are highly dissected and are restricted to the southern part of Pahrump Valley. 


\section{LENGTH}

Length reported in Piety (1994): 50-130 km. Maximum length is from Stewart (1988), and minimum value is from Hoffard (1991).

Length of known Quaternary scarps (this study): $18.5 \mathrm{~km}$

Compelling evidence of Quaternary deformation on the PSV is present in only a few areas of Pahrump and Stewart Valleys. Our length estimate of $18.5 \mathrm{~km}$ is based on the distance between the northwesternmost and southeasternmost features that we interpret as unequivocal evidence of late Quaternary deformation. The northwestern feature is an unusual closed depression on the southeastern side of Stewart playa (CD in fig. 5), and the southeastern feature is a small, distinct scarp in playa deposits located 4-6 km south of Pahrump (PSV-1 in fig. 5).

Southeast of the playa scarp in southern Pahrump Valley, the PSV is marked by two kinds of features: (1) sinuous, 8- to 15-m-high escarpments (fig. 5) and (2) vegetation and tonal lineaments, fissures, and aligned patches of cemented alluvial-fan deposits in the medial parts of the valley (Hoffard, 1991). We do not include these features in our length estimate because there is no convincing evidence that they represent significant Quaternary movement. As a result, our estimated length of the PSV is shorter than the lengths cited by other investigators. Below, we summarize the evidence used by others to define the PSV's length. It is important to note that none of these other studies defined the length solely on evidence of significant Quaternary faulting.

Hoffard (1991) interpreted the main trace of the PSV in the southern Pahrump Valley to coincide with prominent escarpments that expose sediment of Tertiary or early Quaternary age in the uplifted blocks. The escarpments probably mark the location of faults associated with the PSV, but the escarpment's dissected and eroded character indicate little or no late or middle Quaternary displacement. Thus, the escarpments are probably fault-line scarps rather than true fault scarps. Directly southeast of the playa scarp (PSV- 1 in fig. 5), Hoffard (1991) mapped an eroded scarp (ES in fig. 5), which is at least $6.8 \mathrm{~m}$ high; this scarp is also probably a fault-line scarp and is not included in our length estimate.

The tectonic significance of the lineaments, fissures, and cemented fan deposits in southern Pahrump Valley is unclear, but they lack evidence of significant surface offset. Abundant rainfall made it impossible for us to examine these features in the field, but we supplemented our aerial-photograph study of them with the information from Hoffard (1991), who examined them in the field. We found no evidence of Quaternary faulting on these features, so we did not include them in our length estimate.

The northwestern and southeastern ends of the PSV are poorly defined. At the northwestern end, some investigators (see Piety, 1994) have suggested that the PSV may extend across the drainage divide at the northern end of Stewart Valley and connect with faults such as the Ash Meadows (AM) or Amargosa River fault zones (AR) in the Amargosa Desert. During our examination of 1:12,000-scale, low-sun-angle aerial photographs, we found no scarps, lineaments, or geomorphic evidence suggestive of Quaternary faulting in a 15- to 20-km-long gap between Stewart Valley and the Amargosa Desert. The trace of the Stewart Valley fault shown by Burchfiel and others (1983) in northern Stewart Valley projects across late or middle Pleistocene alluvium in several locations and into an area of Quaternary-Tertiary alluvium (McKittrick, 1988). Thus, unfaulted Quaternary deposits at least several-hundred-thousand years old cross the mapped trace of the Stewart Valley fault. We conclude that Quaternary deformation along the PSV is confined to Pahrump and Stewart Valleys and does not connect with the AM or AR.

The southeastern end of PSV is also difficult to define. Unequivocal evidence of Quaternary faulting extends no more than about $10 \mathrm{~km}$ south of Pahrump; however, the PSV probably extends much farther to the southeast in the subsurface. Hoffard (1991, p. 49) identified lineaments and (or) scarps on high-altitude imagery that extend to Black Butte, which forms the drainage divide between the southeastern end of 
Pahrump Valley and Mesquite Valley to the southeast. If the PSV ends near Black Butte, then the zone is $54-59 \mathrm{~km}$ long. However, gravity and magnetotelluric data suggest the zone might extend further southeast along the northeastern edge of the Mesquite Valley basin and into the Stateline Pass area of southern Mesquite Valley (MIT Field Geophysics Course, 1985). There is no evidence of faulting in late Quaternary(?) deposits in Mesquite Valley (MIT Field Geophysics Course, 1985). If the PSV does extend from Stewart playa on the north to Stateline Pass on the south, then its length is $91 \mathrm{~km}$.

STYLE OF FAULTING: Inferred right-lateral slip during the Quaternary

The sense of Quaternary slip on the PSV is inferred to be right-lateral mainly because this is the style of deformation interpreted from studies of pre-Cenozoic rocks (Burchfiel and others, 1983; Stewart, 1988). Stewart (1988) reported 16-19 km of cumulative right-lateral slip on the PSV based on offset Precambrian and Paleozoic sedimentary rocks. Burchfiel and others (1983) reported that the Stewart Valley fault zone is expressed as a 100-m-wide network of anastomosing, northwest-striking, high-angle faults at the extreme southern end of the Montgomery Mountains south of High Peak (EXP in fig. 5). They defined the strike of the Stewart Valley fault zone by connecting this exposure with an area at the northern end of Stewart Valley where Paleozoic rocks have opposing dips in closely spaced but isolated hills. Thus, detailed bedrock mapping in Stewart Valley indicates the presence of a northwest-trending fault zone, but the net-slip direction is not readily apparent from these studies.

The best evidence of late Quaternary lateral slip on the PSV is a closed depression in late Quaternary playa deposits near the southeastern shore of Stewart playa (CD in fig. 5). The 200-m-long, 50-m-wide, 3-m-deep depression could be a small basin that has formed where the fault strands have a more northerly trend, which favors localized extension in the current stress field. To the southeast directly south of California Highway 178, we measured a few tens of centimeters of change in the throw direction along about a 0.5$\mathrm{km}$-long section of a scarp at the southern end of Stewart Valley. The change in throw direction suggests lateral slip, but we were not able to determine the sense of the lateral slip.

\section{DISPLACEMENT AND AGE}

Range of observed surface offset and scarp height representing the youngest movement: $\geq 0.7 \mathrm{~m}$ (surface offset) and more than $0.7 \mathrm{~m}$ to less than about $2.0 \mathrm{~m}$ (scarp height)

Scarps are rare along the PSV, and those that are present are formed on silty playa deposits. Scarps on these deposits are as much as $5 \mathrm{~m}$ high (Hoffard, 1991; fig. 5), but because they are formed on relatively soft deposits, they erode easily. As a result, we were unable to identify multiple surface-faulting events.

The scarp in playa deposits about $4 \mathrm{~km}$ south of Pahrump is probably a single-event scarp because it is small and far enough away from the center of the valley that it could not be the result of stream erosion. This scarp is as much as 1.5-2 $\mathrm{m}$ high and has been extensively modified by erosion from off-road traffic along its northern part; so we selected a profile site along its southern part where it is less than $1 \mathrm{~m}$ high (fig. 6).

Estimated age of most recent surface-faulting event: early to middle(?) Holocene

Age estimates for scarps along the PSV are poorly constrained because Quaternary deposits along the fault zone are largely unstudied. Thus, our inferred age of faulting is not constrained by quantitative data. Distinct scarps on easily eroded playa sediment indicate the youthfulness of faulting particularly in the Stewart Valley area. At a site midway between Stewart playa and California Highway 178 (WPS in fig. 5), a prominent, west-facing, linear berm vertically offsets playa deposits about $3.6 \mathrm{~m}$ (Hoffard, 1991, p. 71). On the east side of the berm, originally westward-sloping playa deposits have been uplifted and warped and now slope $1^{\circ}-1.5^{\circ}$ to the east. The lack of extensive rills or erosion indicate that this berm is probably Holocene in age. 


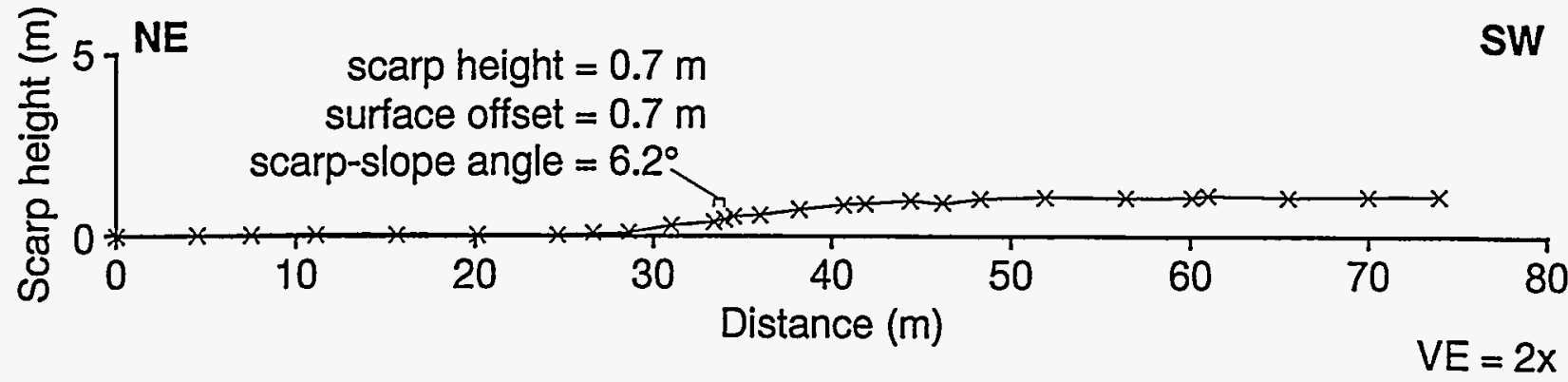

Figure 6. Profile of fault scarp along the Pahrump-Stewart Valley fault zone (PSV) at location PSV-1 shown in figure 5. The scarp is formed on unconsolidated, silty playa deposits that erode easily and degrade to rounded morphology in a few thousand years.

A scarp formed on silty playa deposits should degrade much more rapidly than a similar size scarp on alluvial-fan gravels, thus, the scarp's morphology should appear older than its actual age. From the plot of profile PSV-1 (fig. 7), the relative age of the playa scarp south of Pahrump is younger than Lake Bonneville shoreline scarps, and we speculate that it might be early or middle Holocene in age.

Range of observed total surface offset along scarps on alluvium: maximum of about $5 \mathrm{~m}$ on late Quaternary deposits (from Hoffard, 1991); 8-15 $\mathrm{m}$ in Tertiary or early(?) Pleistocene lacustrine deposits

Large scarps on Quaternary deposits are confined to the Stewart Valley part of the PSV. Three- to 5-m-high scarps on soft playa sediment suggest multiple late Quaternary surface-faulting events. However, the large scarps are all within $0.5-0.6 \mathrm{~km}$ of the axis of Stewart Valley, where fluvial erosion may have increased the size of a scarp. The largest scarp reported by Hoffard (1991) (5-m-high scarp in fig. 5) probably is eroded, so it is a fault-line scarp rather than a fault scarp.

The 8- to 15-m-high escarpment (fault-line scarp) in southern Pahrump Valley probably reflects the location of faults that affect the ground-water flow in the valley (Quade and others, 1995). The topographic relief on the escarpment offers a first-order estimate of the long-term dip-slip movement on this part of the fault zone because the relief is largely the product of faulting. There are few geologic constraints on the age of the faulting other than fault movement has exposed fine-grained sediment that is inferred to be either Tertiary or early Pleistocene in age. If we assume that the sediments are early Pleistocene and that they are vertically displaced about $15 \mathrm{~m}$, then the inferred maximum vertical slip rate is about $0.02 \mathrm{~mm} / \mathrm{yr}$ ( $15 \mathrm{~m} / 770 \mathrm{k} . \mathrm{y}$.$) . If the sediments are latest Pliocene in age, then the rate is 0.009 \mathrm{~mm} / \mathrm{yr}(15 \mathrm{~m} / 1650 \mathrm{k} . \mathrm{y}$.$) .$ Thus, the long-term vertical slip rate on the southern part of the PSV is less than a few hundredths of a millimeter per year and is most likely on the order of thousandths of a millimeter per year.

We know of no geologic constraints on the amount of Quaternary lateral slip on the fault zone. Stewart (1988) reported 16-19 km of right-lateral offset on Paleozoic and Precambrian rocks, but the timing of this offset is unknown. Stewart noted that many faults in the Walker Lane belt originated in Mesozoic time and have been reactivated in the Cenozoic. Geologic studies in the Yucca Mountain area indicate that the most recent major episode of regional Cenozoic deformation ceased between about 11.5-12.5 m. y. ago (Carr, 1988). Mesozoic and early Cenozoic deformation was so widespread and pervasive in the region that it probably produced most of the lateral slip on the PSV. The limited expression of the PSV in Quaternary deposits is evidence that the fault zone's long-term Quaternary slip rate is low. 


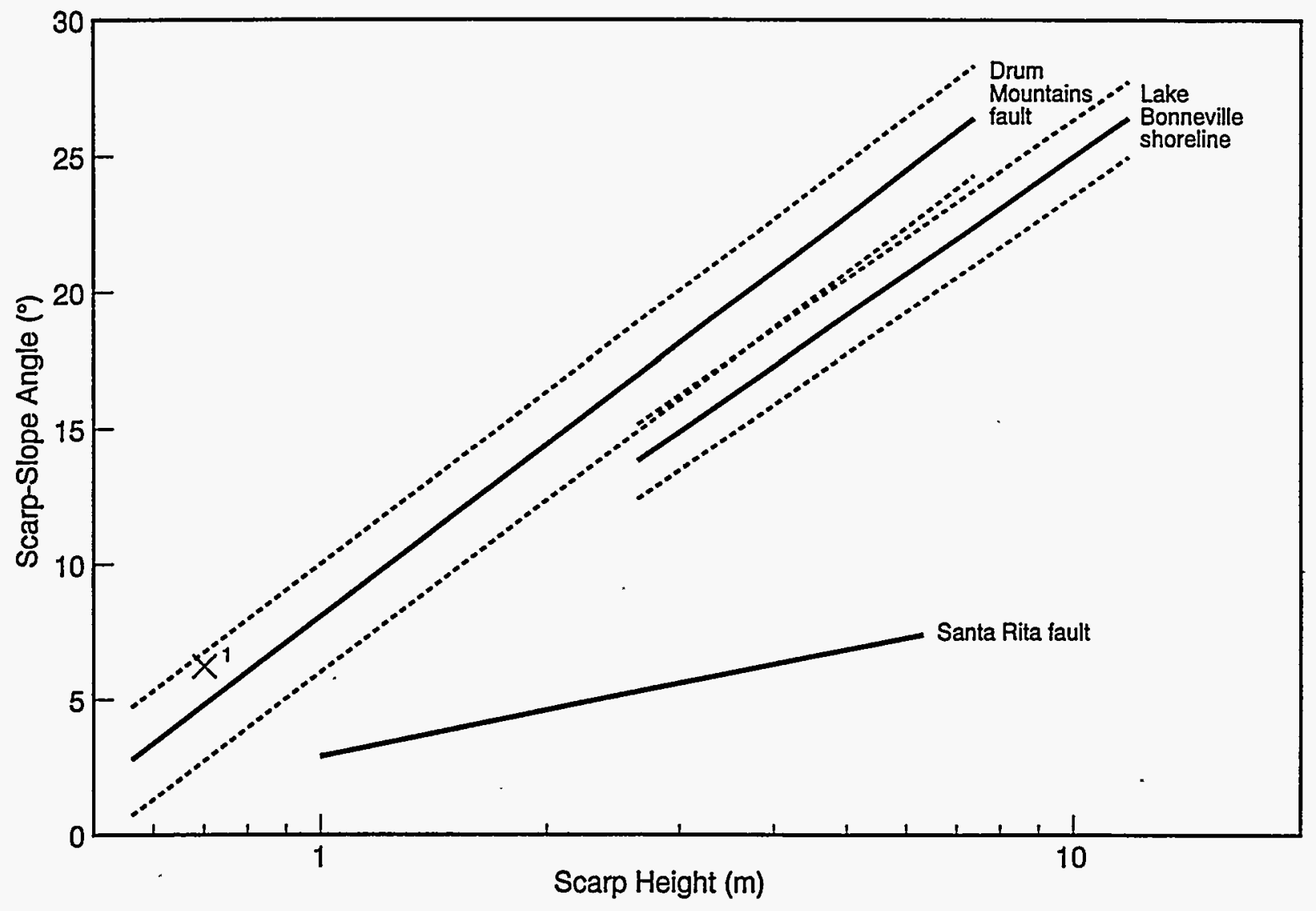

Figure 7. Plot of scarp-height-slope-angle value for scarp formed on easily eroded, silty playa sediment along Pahrump-Stewart Valley fault zone (PSV). Profile of scarp shown in figure 6. Solid lines, regression lines for reference scarps; dotted lines, 1- $\sigma$ limits for regressions. Lake Bonneville shoreline scarp (about $15 \mathrm{ka}$; Machette, 1989) and Drum Mountains fault scarp (about $10 \mathrm{ka}$; Crone, 1983) both from Bucknam and Anderson (1979); Santa Rita fault scarp (estimated age about $100 \mathrm{ka}$; Pearthree and Calvo, 1987). Points that plot above or below the 1- $\sigma$ limits of a regression line suggest relative ages that are younger or older than those of the reference scarps, respectively. 


\section{AMARGOSA RIVER FAULT ZONE (AR)}

SUMMARY: The Amargosa River fault zone (AR) is a diffuse band of scarps that extends northwest across the central Ash Meadows portion of the Amargosa Desert, directly east of the California-Nevada boundary. The fault zone has a strike of $\mathrm{N} .47^{\circ} \mathrm{W}$., but individual scarps trend $\mathrm{N} .30^{\circ}-57^{\circ} \mathrm{W}$. The only strong evidence for Quaternary strike-slip motion is from a 40 - to 50-m-wide left step in a previously unmapped strand. If the left step is associated with compressional deformation, the lateral component of slip is right lateral. The youngest movement is probably late Pleistocene rather than Holocene, as suggested by others. We found no scarps from this event that could yield reliable values of scarp height or surface offset. Most scarps associated with the fault zone are either modified by fluvial erosion or deposition or are on dissected or truncated Tertiary(?) sediment. The few scarps that we observed have small vertical offsets and unknown amounts of horizontal offset. The only information pertinent to recurrence intervals or slip rates on the AR is our estimate that more than $10 \mathrm{k}$. y. have elapsed since the most recent faulting event.

LOCATION: The AR as defined by Donovan (1991) is a diffuse band of scarps that extend northwest across the Ash Meadows portion of the Amargosa Desert, directly east of the California-Nevada boundary.

The AR as defined by Donovan (1991) is comprised of a few fault scarps, linear reaches of stream channels that lie along older faults and scarps, and many vegetational and tonal lineaments associated with faults in Quaternary and Tertiary sediment. Collectively, these features form a diffuse band that extends northwest across the central Ash Meadows portion of the Amargosa Desert, 1-4 km east of the California-Nevada boundary. For most of its length, the AR parallels the Amargosa River. Donovan (1991, fig. 3, 4) restricts the $A R$ to a narrow band of faults and includes many other features in the diffuse band as a secondary fault zone based on orientation. Donovan (1991) omitted a prominent scarp that strikes north-northwest through sec. 31 (T. 17 S., R. 50 E.) and sec. 6 (T. 18 S., R. 50 E.) from her compilation. This scarp probably has been eroded by streams; however, a distinct 40 - to 50 -m-wide left step at its northern end suggests that the scarp is also a product of strike-slip faulting (see later discussion about sense of movement). The AR has been interpreted by Donovan (1991) as the northwestern extension of the Pahrump-Stewart Valley fault zone (PSV). Our analysis indicates that the two fault zones are different systems, separated by a 15 - to $20-\mathrm{km}$-long gap that lacks evidence of Quaternary faulting (see discussion of PSV). The AR seems to end at its intersection with the Rock Valley fault zone (RV) on the northwest and the Ash Meadows fault zone (AM) on the southeast; its lateral extent may be controlled by movement on the RV and AM. However, the northwesterly trend of the AR also seems to be controlled by Tertiary structures, which have been reactivated in the Quaternary.

ORIENTATION: N. $47^{\circ} \mathrm{W}$., but individual scarps trend N. $30^{\circ}-57^{\circ} \mathrm{W}$.

As defined by Donovan (1991), the AR is comprised of discontinuous, en echelon, northwest-trending scarps. Within the zone, most scarps are within about $10^{\circ}$ of the overall N. $47^{\circ} \mathrm{W}$. trend as defined from the designated end points (see discussion of fault length below). Faults within the secondary fault zone of Donovan (1991) are more northerly, and have individual trends of N. $25^{\circ} \mathrm{W}$. to N. $35^{\circ} \mathrm{E}$. These trends are similar to those along the AM to the east, and thus may be related. 


\section{LENGTH}

Length reported in Piety (1994): $15 \mathrm{~km}$

Length of known Quaternary scarps (this study): $11.8 \mathrm{~km}$

The total length of the AR (fig. 8) as recorded by Donovan (1991) is $15 \mathrm{~km}$ (measured from sec. 17, T. 17 S., R. 49 E. southeastward to sec. 16, T. 18 S., R. 50 E., Franklin Well 7.5' quadrangle). The southeastern end of the AR includes fractures and faults in eroded Tertiary strata (Donovan, 1991, pl. 1); because none of the features in this area show evidence of Quaternary deformation, they are not included in our length of known Quaternary scarps. The southeastern end of the active AR is a fluvially eroded scarp (scarp channel of Donovan, 1991) in the NE $1 / 4$ sec. 7 (T. 18 S., R. 50 E., Franklin Well 7.5' quadrangle) and the northwestern end is another scarp channel in the $\mathrm{NE}^{1} / 4 \mathrm{sec} .17$ (T. $17 \mathrm{~S} .$, R. 49 E., Franklin Well 7.5 quadrangle). The AR between these two scarps has a straight-line length of $11.8 \mathrm{~km}$; a length along trace could not be measured because of the discontinuous, en echelon nature of faulting.

STYLE OF FAULTING: Probably right-lateral (dextral) strike slip. Where an oblique normal component is present, the down-dip component alternates between northeast and southwest.

Donovan (1991) inferred right-lateral slip on the AR because she assumed it is a continuation of the Pahrump-Stewart Valley fault zone (PSV). However, we found no direct evidence to define the amount of offset or style of Quaternary faulting on the PSV. We examined several exposures of the AR mapped by Donovan (1991) and found that the orientation of faulting is probably related to reactivation of Tertiary (Miocene-Pliocene?) strike-slip faults. For example, faults exposed in a deep arroyo channel in the SW'1/4 $\mathrm{SW}^{1} / 4 \mathrm{SE}^{1} / 4$ sec. $35, \mathrm{~T}$. $17 \mathrm{~S} ., \mathrm{R} .49 \mathrm{E}$. (Franklin Well 7.5' quadrangle) strike N. $35^{\circ} \mathrm{W}$., parallel to scarps and lineations in Quaternary deposits to the north and east. The faults in the arroyo tilt Tertiary lacustrine sediment and tufas to the northeast $10^{\circ}-12^{\circ}$; some of these same faults cut the overlying gravel (Quaternary?) and some do not, showing partial reactivation of older faults. Likewise, near the northern end of the AR, vegetation lineaments mapped by Donovan (1991) are controlled by fractures and faults in Tertiary sediment that is beneath a thin cover of unfaulted Quaternary eolian and fluvial sediment.

The only compelling evidence for Quaternary strike-slip motion along the AR comes from the previously mentioned 40- to 50-m- wide left-step, which Donovan (1991) and other compilers (Reheis and Noller, 1991) did not map. On low-sun angle photographs, the downdropped (northeast) side of the fault seems to be bowed up in a ramp between the left-stepping sections (LS in fig. 8), indicating that the step is associated with compression and, thus, right-lateral slip.

\section{DISPLACEMENT AND AGE}

Range of observed surface offset and scarp height representing the youngest movement: unknown

We cannot estimate the amount of surface offset and scarp height caused by the youngest movement on the AR. Most of the scarps associated with the AR are either eroded by streams (scarp channels of Donovan, 1991), or are on dissected or truncated Tertiary(?) sediment. The few scarps that we observed in the field (table 3) have small vertical offsets and unknown amounts of horizontal offset. Donovan (1991, pl.1) mapped other scarps on the basis of vegetation or tonal lineaments including the 5.6-m-high fluvial terrace scarp (TS in fig. 8) in the NW1/4 sec. 20 (T. 17. S., R. 49 E., Franklin Well 7.5' quadrangle). The lineament on trend with this scarp is probably caused by fracturing of the underlying Tertiary strata, which allowed the Amargosa River to easily erode laterally into the eastern (downdropped) block. 


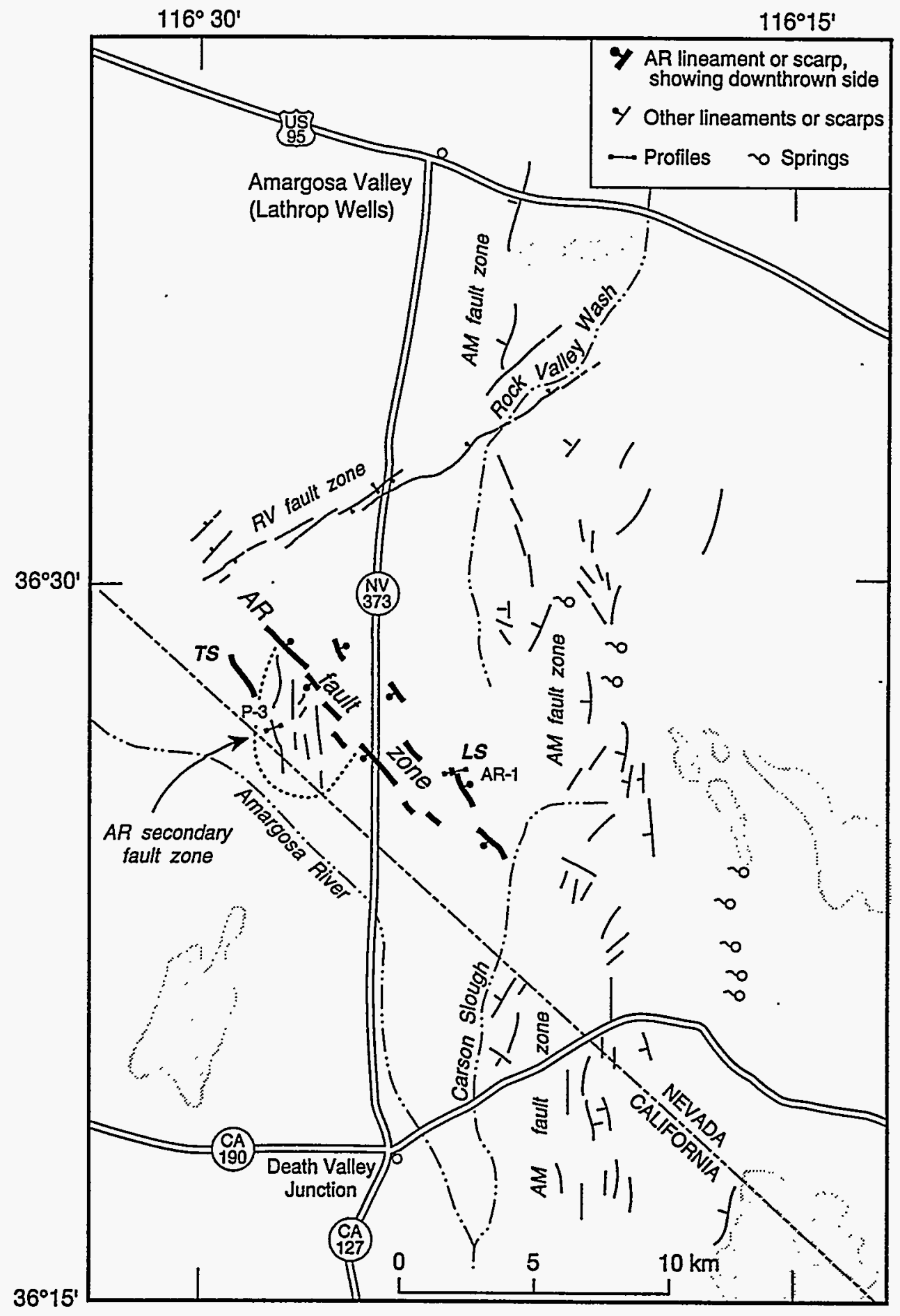

Fiqure 8. Map of the Amargosa River fault zone (AR) and selected geographic and cultural features in the Amargosa Valley. Features associated with Donovan's (1991) secondary fault zone are enclosed by dotted line. Abbreviations include $A M$, Ash Meadows fault zone and RV, Rock Valley fault zone, southwestern extension. Location of scarp profiles listed in table 3 are shown by bar symbol. 
TABLE 3. Scarp-profile data for the Amargosa River fault zone, southern Nevada.

[Some parameters estimated from a scarp profile P-3 $\ddagger$ shown in Donovan (1991, Appendix A). Fault parameters as defined in figure 2: LS, lower surface angle; US, upper surface angle; SO, surface offset; SH, scarp height; $\theta$, scarp-slope angle; e, estimated; ?, questionable.]

\begin{tabular}{cccccccc}
\hline $\begin{array}{c}\text { Profile } \\
\text { No. }\end{array}$ & \multicolumn{1}{c}{ Fault } & $\begin{array}{c}\text { Scarp type, } \\
\text { aspect }\end{array}$ & LS & US & $\begin{array}{c}\text { SO } \\
(\mathrm{m})\end{array}$ & $\begin{array}{c}\text { SH } \\
(\mathrm{m})\end{array}$ & $\theta$ \\
\hline AR-1 & Main fault zone & Dextral(?), E & $2.1^{\circ}$ & $1.5^{\circ}$ & $2.5-3.0$ & $>1.6$ & $5.0^{\circ}$ \\
P-3 $\neq$ & Secondary fault zone & Unknown, W & $0.5^{\circ} \mathrm{e}$ & $0.5^{\circ} \mathrm{e}$ & $1.1 \mathrm{e}$ & $1.3 \mathrm{e}$ & $3.5^{\circ}$ \\
\hline
\end{tabular}

Estimated age of most recent surface-faulting event: late Pleistocene

Although Piety (1994) lists Holocene for the age of the most recent surface-faulting event, this estimate depends on the age of surfaces on which scarps and lineaments have been mapped. Our field work indicates that much of the AR is mapped on surfaces that are formed on eroded Tertiary sediment; parts of these surfaces have been preserved by erosion-resistant tufas and calcretes. The 5.6-m-high fluvial terrace scarp (TS in fig. 8) has an old, degraded morphology (large height and low scarp-slope angle of $<5^{\circ}$ ). On figure 9, this scarp would plot below the regression line for the Santa Rita scarps, which Pearthree and Calvo (1987) estimated to have formed about $100 \mathrm{ka}$. Evidence for the youngest movement along the scarp is recorded by the seemingly young morphology of the left step in sec. 31 (LS in fig. 8) and by profile AR-1 (table 3, appendix B). The terrace on the downdropped northeast side has at least a weak soil (Av and B horizon), is covered by a mantle of younger (Holocene?) eolian sand, and is about $6 \mathrm{~m}$ above modern stream level. From the low elevation and soil development we infer that the terrace is pre-Holocene and probably latest Pleistocene in age. The age of the uplifted surface to the southwest is poorly constrained; from shallow pits, the surface appears to be mantled by a well-developed petrocalcic horizon or tufa, although these may in part be Tertiary in age, like other deposits seen along the AR. In places the scarp is quite prominent, probably as a result of the presence of an erosion-resistant surface and vegetation that traps eolian sand along the scarp.

Range of observed total surface offset along scarps on alluvium: unknown

As previously mentioned, most scarps associated with the AR are either modified by fluvial erosion or deposition or are on dissected or eroded Tertiary(?) sediment. The more than $1.6 \mathrm{~m}$ of vertical surface offset measured on alluvium from profile AR-I (appendix B) at the left step in sec. 31 (LS in fig. 8) is a minimum value because similar-age surfaces may not be present on both sides of the fault. Donovan's profile P-3 (appendix B) is for a scarp in the secondary fault zone that has about $1.1 \mathrm{~m}$ (estimated) of surface offset.

Estimates of recurrence intervals and slip rates: $>10 \mathrm{k} . \mathrm{y}$. and unknown

The only information pertinent to recurrence intervals is the amount of time since the most recent faulting event (>10 ka, pre-Holocene). No information about slip rates was obtained from the literature or this study. 


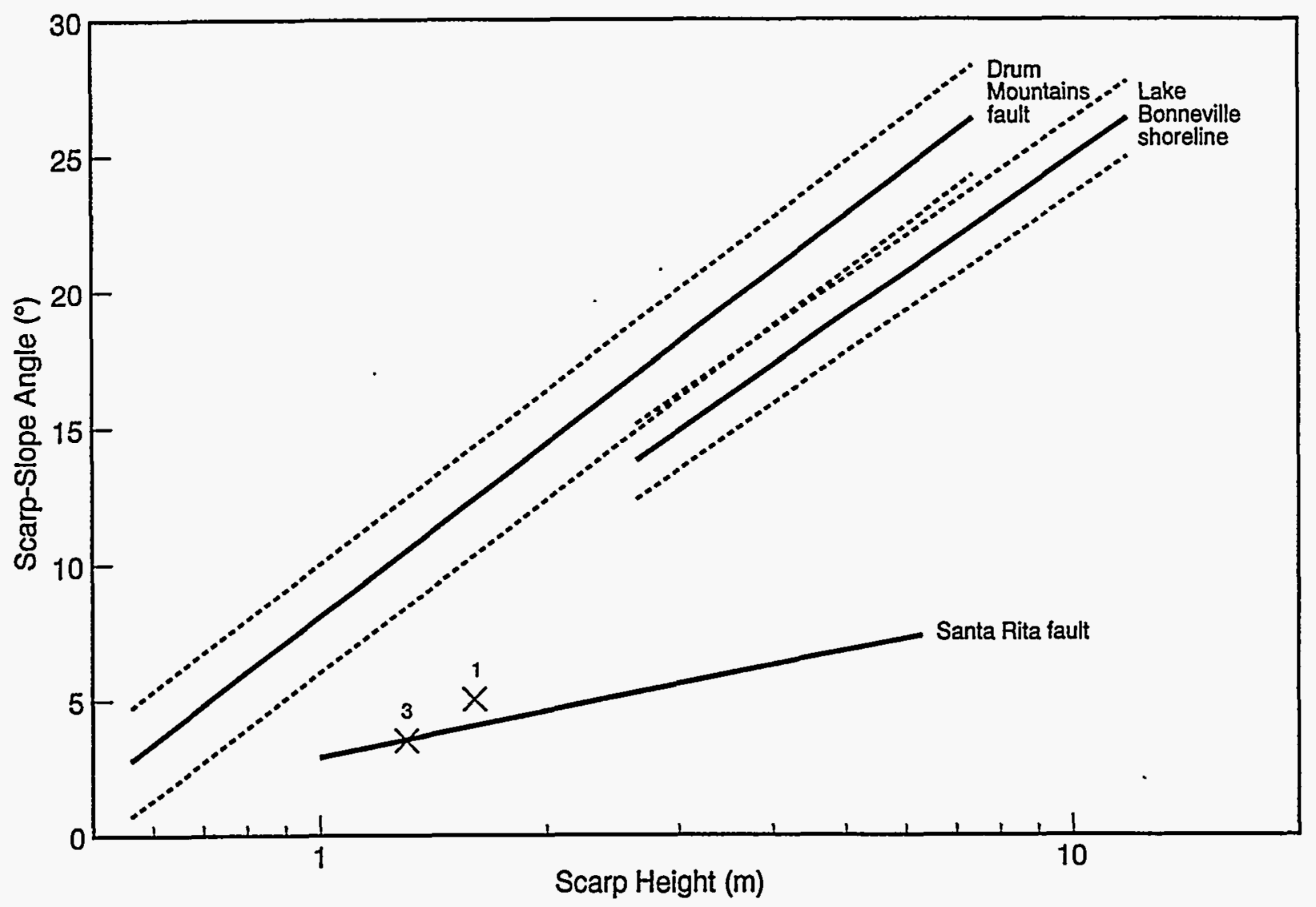

Figure 9. Plot of scarp-height-slope-angle values for scarps on alluvium along the Amargosa River fault zone (AR). Data point 1 is plot for profile AR-1 and data point 3 is for profile $P-3$; site numbers shown in figure 8 and table 3 . Solid lines, regression lines for reference scarps; dotted lines, 1- $\sigma$ limits for regressions. Lake Bonneville shoreline scarp (about $15 \mathrm{ka}$; Machette, 1989) and Drum Mountains fault scarp (about $10 \mathrm{ka}$; Crone, 1983) both from Bucknam and Anderson (1979); Santa Rita fault scarp (estimated age about $100 \mathrm{ka}$; Pearthree and Calvo, 1987). Points that plot above or below the 1- $\sigma$ limits of a regression line suggest relative ages that are younger or older than those of the reference scarps, respectively. 


\section{EAST NOPAH FAULT (EN)}

SUMMARY: The East Nopah fault (EN) forms $19 \mathrm{~km}$ of scarps along the northeastern flank of the Nopah Range in Inyo County, California. The northwesterly trending scarps extend from about $13 \mathrm{~km}$ southwest to about $24 \mathrm{~km}$ south of the town of Pahrump, Nevada. Overall, the scarps trend N. $33^{\circ} \mathrm{W}$., but individual sections of scarps span azimuths between N. $8^{\circ}$ E. to N. $30^{\circ} \mathrm{W}$. Near the surface, the fault is nearly vertical and the Quaternary slip is probably oblique (right-lateral normal). Surface offsets and scarp heights of single-event scarps on late Pleistocene deposits are variable, but are typically 1.1-1.9 m. The most recent surface-faulting event may have occurred $30-40 \mathrm{ka}$, but could be significantly older (50-100 ka). Scarps on middle to early Pleistocene alluvium appear to record multiple events. Although poorly constrained, the late to middle Pleistocene vertical slip rate on the EN may be about $0.02-0.004 \mathrm{~mm} / \mathrm{yr}$. The recurrence interval between surface-faulting earthquakes is probably several tens of thousands to hundreds of thousands of years.

LOCATION: The EN forms scarps along the northeastern flank of the Nopah Range, Inyo County, California, which is the range that bounds the southwestern side of Pahrump Valley and trends subparallel to the California-Nevada state boundary (fig. 10). The EN scarps trend northwesterly across the piedmont fans about $0.5 \mathrm{~km}$ east of the range front and about $3-5 \mathrm{~km}$ southwest of the state line. The scarps extend from about $13 \mathrm{~km}$ southwest to about $24 \mathrm{~km}$ south of the town of Pahrump, Nevada.

ORIENTATION: The overall trend of the EN is about N. $33^{\circ}$ W., but individual sections of the scarps have trends that span azimuths between N. $8^{\circ}$ E. to N. $30^{\circ}$ W. (Hoffard, 1991). Individual fault strands, scarps, and calcified fractures trend between $\mathrm{N} .13^{\circ} \mathrm{E}$. and N. $35^{\circ}$ W., but most of these features trend between north-south and N. $20^{\circ} \mathrm{W}$.

\section{LENGTH}

Length reported in Piety (1994): 17-19 km (from Hoffard, 1991)

Length of known Quaternary scarps (this study): $19 \mathrm{~km}$

The scarps examined in the field extend from the NW1/4 sec. 3, T. 23 N., R. 8 E., Sixmile Spring 7.5' quadrangle, to the $\mathrm{SE}^{1 / 4}$ sec. 33, T. 22 N., R. 9 E., North of Tecopa Pass 7.5' quadrangle. The fault length defined here excludes a group of discontinuous scarps mapped by McKittrick (1988) that are located about $2.5 \mathrm{~km}$ southwest of the southern end of the EN (fig. 10). We do not include these southwestern scarps because they are separated from the EN by a large, high rib of Paleozoic bedrock and because they trend northeasterly rather than northwesterly as does the main EN. The bedrock rib and the change in scarp trend suggest that the southwestern scarps are part of a separate fault.

STYLE OF FAULTING: Inferred oblique (right-lateral normal) slip

The sense of slip during Quaternary faulting events is uncertain, but field evidence indirectly suggests a major component of right-lateral slip. The pattern of scarps on Quaternary deposits is an anastamosing zone of multiple strands more than $100 \mathrm{~m}$ wide. Along the north-central part of the EN (secs. 13 and 14, T. 23 N., R. 8 E., Nopah Peak 7.5' quadrangle), the network of scarps is about $1 \mathrm{~km}$ wide, and the throw on individual strands is either down-to-the-east or down-to-the-west. Some strands produce broad, gentle warps in the alluvial-fan surfaces that merge into distinct scarps when traced along strike. The width of the 


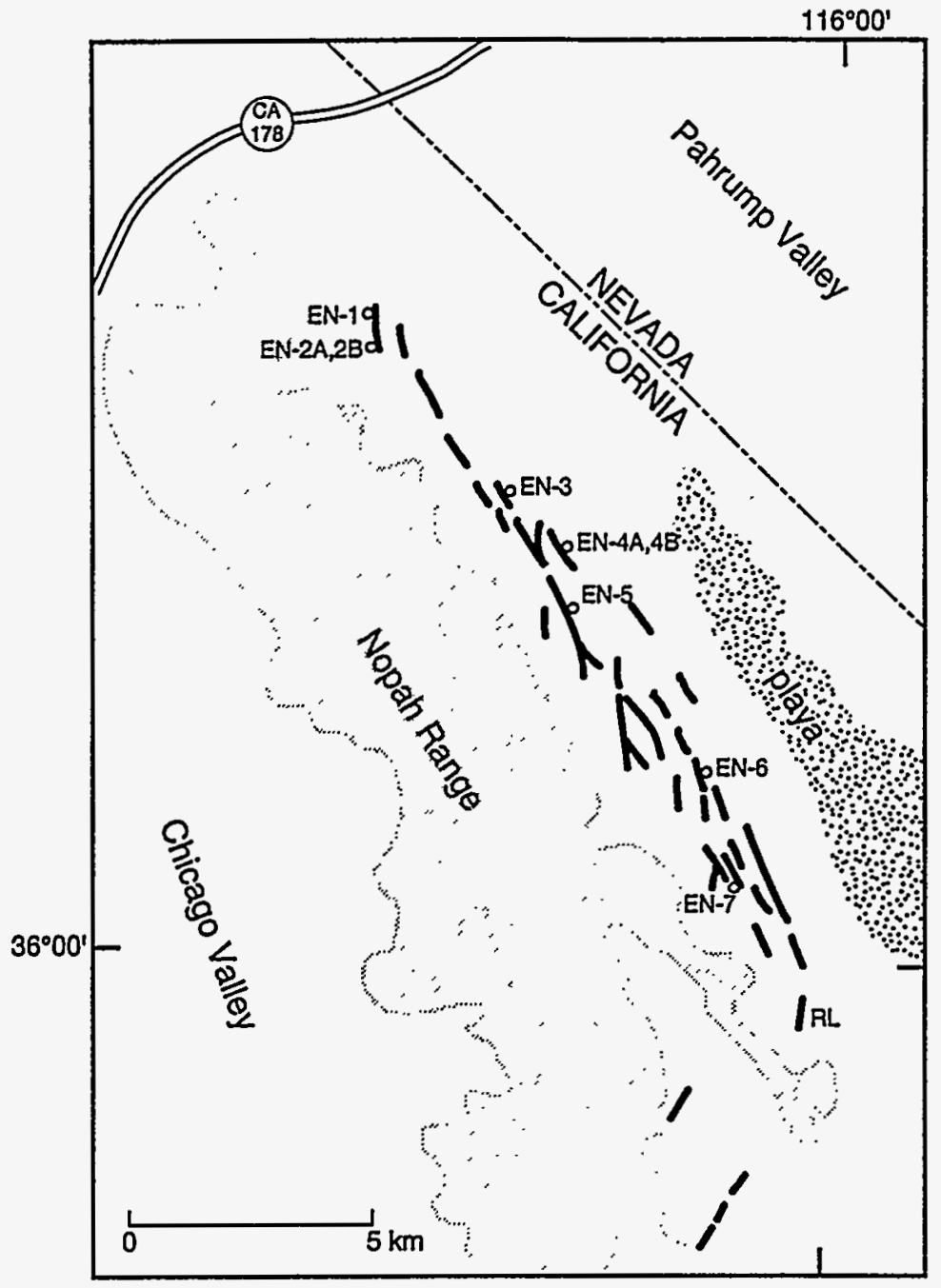

Figure 10. Generalized map of Quaternary fault scarps along the East Nopah fault, Inyo County, California (modified from McKittrick, 1988 and Piety, 1994). Extent of mostly continuous bedrock shown by half-tone fill. About $19 \mathrm{~km}$ of Quaternary scarps are shown in bold lines. Northeasttrending scarps at southern end of range are not included in this length measurement because they are separated from range-front scarps by a large bedrock ridge. Open circles are locations of scarp profiles listed in table 4. RL identifies location of speculative right-lateral slip.

fault zone and the variable sense of throw suggest a significant component of lateral slip. Furthermore, the scarps commonly have a left-stepping pattern of offsets at scales ranging from faults (see maps of Hoffard, 1991) to individual fault strands. Such left-stepping patterns are common in lateral-slip fault systems.

The near-surface attitude of the EN is almost vertical. We measured the strike and dip of calcified fractures and faults in six natural exposures formed by incised arroyos. At all of these locations, the fractures and faults are associated with deformation on the adjacent fan surfaces. Nearly all of the faults and fractures dip steeply between $80^{\circ} \mathrm{W}$. and $76^{\circ} \mathrm{E}$; such opposing steep dips are also typical of lateral-slip faults.

The most prominent scarps are down-to-the-east. Locally, fault-related tilting has flattened the eastsloping fan gradient to nearly horizontal or slightly westward sloping. Although broad grabens disrupt the gradient of the alluvial fans at several locations (fig. 11), the net vertical offset across them is small (about 1-1.5 m). Wide grabens having nominal amounts of net throw are typical of lateral-slip faults.

We found weak evidence of right-lateral offset at one site near the southern end of the fault zone (RL in fig. 10). Here, a fault with a small amount of down-to-the-west throw offsets a southeasterly sloping alluvial fan. A small, eastward-flowing arroyo may be deflected as much as $12 \mathrm{~m}$ right laterally at the trace of the fault, although the apparent lateral offset could also have been caused by headward erosion of a stream, which breached the small west-facing escarpment. The amount of apparent right-lateral slip is unexpectedly 


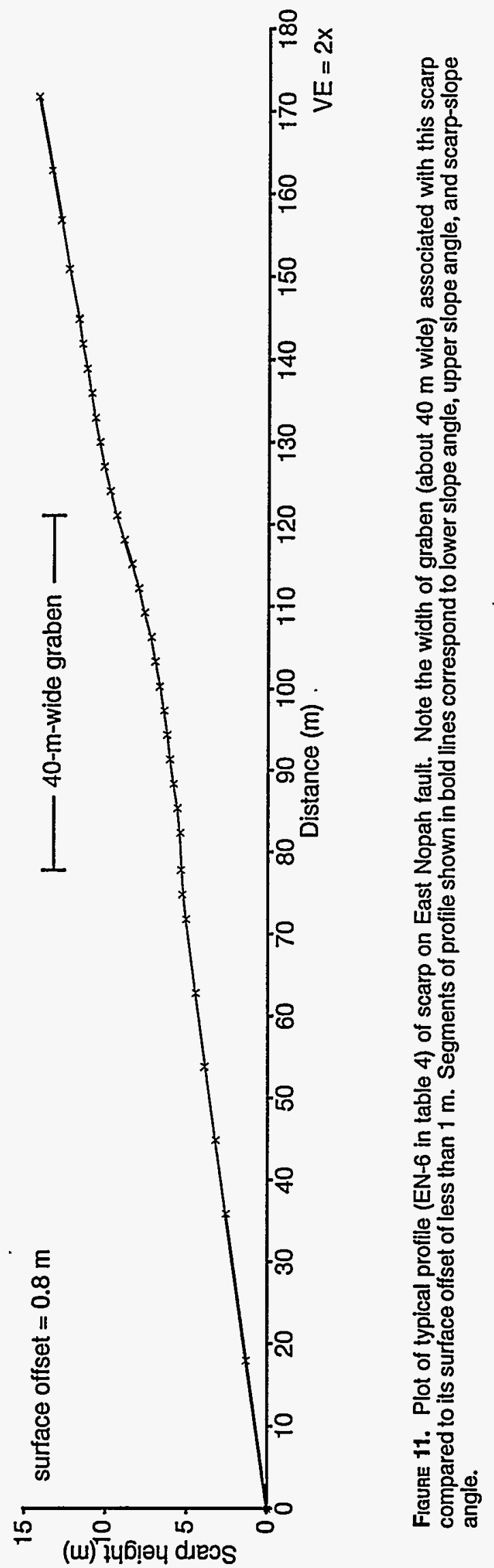


TABLE 4. Scarp-profile data for the East Nopah fault, eastern California.

[Positive surface and scarp angles denote normal geomorphic gradients; that is, toward basin center and away from sediment sources. Fault parameters as defined in figure 2: LS, lower slope angle; US, upper slope angle; SO, surface offset; SH, scarp height; $\theta$, scarp-slope angle.]

\begin{tabular}{|c|c|c|c|c|c|c|}
\hline $\begin{array}{l}\text { Profile } \\
\text { No. }\end{array}$ & $\begin{array}{l}\text { Scarp type, } \\
\text { aspect }\end{array}$ & LS & US & $\begin{array}{l}\text { SO } \\
\text { (m) }\end{array}$ & $\begin{array}{l}\mathrm{SH} \\
(\mathrm{m})\end{array}$ & $\theta$ \\
\hline $\mathrm{EN}-1$ & Normal, E & $2.3^{\circ}$ & $2.8^{\circ}$ & 1.1 & 1.9 & $6.0^{\circ}$ \\
\hline EN-2A & $\begin{array}{l}\text { Normal, lower of } \\
\text { two scarps, E }\end{array}$ & $2.8^{\circ}$ & $3.2^{\circ}$ & 0.3 & 0.6 & $5.3^{\circ}$ \\
\hline EN-2B & $\begin{array}{l}\text { Normal, upper of } \\
\text { two scarps, E }\end{array}$ & $3.2^{\circ}$ & $3.9^{\circ}$ & 0.5 & 1.1 & $6.4^{\circ}$ \\
\hline EN-3 & Normal, NE & $1.8^{\circ}$ & $2.2^{\circ}$ & 1.0 & 1.4 & $6.5^{\circ}$ \\
\hline$E N-4 A$ & $\begin{array}{l}\text { Normal, lower of } \\
\text { two scarps, NE }\end{array}$ & $2.6^{\circ}$ & $3.1^{\circ}$ & 1.1 & 1.7 & $8.7^{\circ}$ \\
\hline EN-4B & $\begin{array}{l}\text { Normal, upper of } \\
\text { two scarps, NE }\end{array}$ & $3.1^{\circ}$ & $3.2^{\circ}$ & 0.9 & 1.6 & $7.3^{\circ}$ \\
\hline EN-5 & Normal, NE & $3.3^{\circ}$ & $3.5^{\circ}$ & 0.2 & 0.3 & $4.9^{\circ}$ \\
\hline EN-6 & Normal, E & $4.1^{\circ}$ & $5.2^{\circ}$ & 0.8 & 1.6 & 9.0 \\
\hline EN-7 & Normal, NE & $1.7^{\circ}$ & $1.4^{\circ}$ & 2.8 & 4.0 & $4.9^{\circ}$ \\
\hline
\end{tabular}

large at this location, because the site is at the southeastern end of the EN where typically fault displacements should be small. Thus, this evidence of lateral slip is tenuous, but noteworthy.

\section{DISPLACEMENT AND AGE}

Range of observed surface offset and scarp height representing the youngest movement: $0.2-1.1 \mathrm{~m}$ (surface offset) and 0.3-1.9 $\mathrm{m}$ (scarp height)

Surface offsets across individual strands of the fault are typically less than $1 \mathrm{~m}$ (table 4, except profile EN-7); however, these offsets probably do not reflect the total offset if the EN has a significant lateral-slip component. Dip-slip components can vary greatly within short distances on lateral-slip faults depending on the orientation and gradient of geomorphic surfaces traversed by the fault.

Estimated age of most recent surface-faulting event: late to possibly middle Pleistocene

Scarps along the EN are present only on alluvial fans that are estimated to be late to middle(?) Pleistocene in age ( $\left(\mathrm{F}_{2}\right.$ of McKittrick, 1988) or older (Qf $\mathrm{F}_{1}$ and QTf). Alluvium thought to be latest Pleistocene and Holocene in age $\left(\mathrm{Qf}_{3}\right.$ and $\mathrm{Qf}_{4}$ of McKittrick, 1988) is not faulted. Age estimates of the fans are based on soil development and alluvial-fan morphology (McKittrick, 1988). The soil development and morphology of the Nopah Range fans compare well with characteristics of the well-studied alluvial fans of Kyle Canyon, which are about $60 \mathrm{~km}$ to the northeast on the east flank of the Spring Mountains (Sowers, 1986; Reheis and others, 1992). If the Nopah Range fans correlate with the Kyle Canyon fans, then the $Q f_{2}$ deposits along the Nopah Range probably correspond to surface 3 at Kyle Canyon. Soils on surface 3 have been dated by ${ }^{14} \mathrm{C}$ at $10-15 \mathrm{ka}$ and by the uranium-series method at $47 \pm 20$ and $76 \pm 6 \mathrm{ka}$; the deposits appear to represent a timetransgressive late Pleistocene alluvial sequence (Reheis and others, 1992). Thus, if the correlations are correct, the $\mathrm{Qf}_{2}$ deposits (surface 3 ) along the Nopah Range might be as young as $15 \mathrm{ka}$, but actually could be considerably older. The unfaulted $\mathrm{Qf}_{3}$ and $\mathrm{Qf}_{4}$ deposits of McKittrick (1988) would be less than $15 \mathrm{ka}$. 
The faulted $\mathrm{Qf}_{2}$ fans have a well-developed, shallow, calcic to petrocalcic horizon with stage III-IV soilcarbonate morphology (Birkeland, 1984; Machette, 1985). Soils with stage III-IV carbonate morphology are indicative of deposits that are more than $100 \mathrm{k}$. y. old (see table 2 in Machette, 1985). However, laterally flowing, shallow, carbonate-rich ground water can produce laminar carbonate horizons that are similar to pedogenic deposits. Although some of the petrocalcic horizon could be of ground-water origin, sufficient pedogenic carbonate is present in the near-surface of $\mathrm{Qf}_{2}$ deposits to suggest that their age is probably on the order of about $50 \mathrm{k}$. y. rather than $15 \mathrm{k}$. y. as the suggested by the ${ }^{14} \mathrm{C}$ ages at Kyle Canyon.

The morphology of the fault scarps suggests that the age of the most recent event on the EN is no younger than late Pleistocene (fig. 12). The plot of scarp height versus scarp-slope angle suggests that the EN scarps are as old or older than the Lake Bonneville shoreline. However, several factors can make the scarps appear to be either morphologically younger or older than their actual age. One factor is that the scarps may have originally lacked a free face when they formed because fault slip was dominantly lateral. Similarly, scarps produced by small amounts of throw on several closely spaced strands will have a relatively rounded original morphology. In both of these cases, the inferred age of the scarps based on their

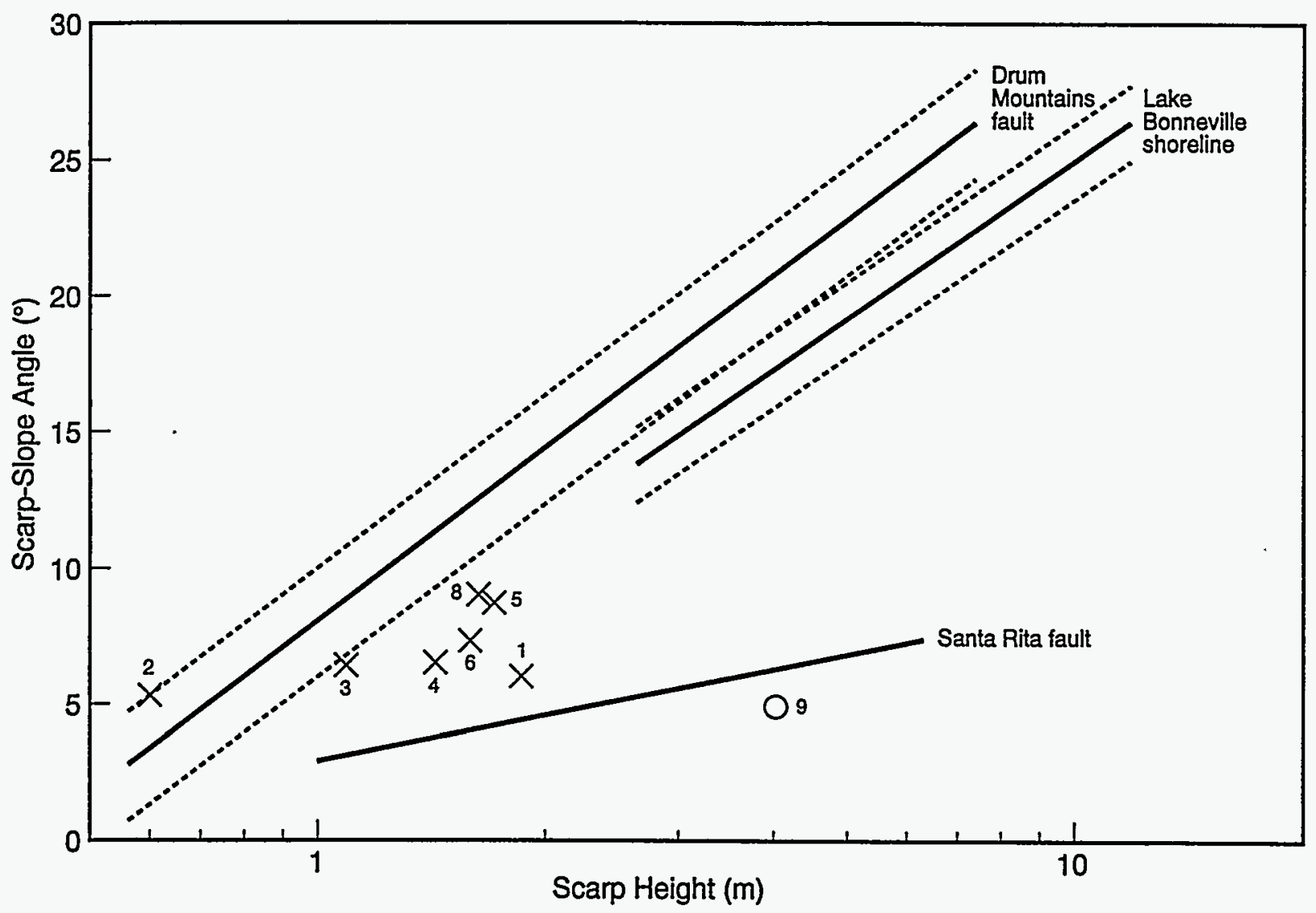

Figure 12. Plot of scarp-height-slope-angle values for scarps on alluvium along the East Nopah fault (EN). Open circle indicates probable multiple-event scarp; $X$ indicates scarps that lack evidence of multiple periods of movement and are inferred to be single-event scarps; site numbers shown in table 4 (profiles $2 B$ and $4 B$ are not plotted). Solid lines, regression lines for reference scarps; dotted lines, $1-\sigma$ limits for regressions. Lake Bonneville shoreline scarp (about $15 \mathrm{ka}$; Machette, 1989) and Drum Mountains fault scarp (about $10 \mathrm{ka}$; Crone, 1983) both from Bucknam and Anderson (1979); Santa Rita fault scarp (estimated age about 100 ka; Pearthree and Calvo, 1987). Points that plot above or below the 1- $\sigma$ limits of a regression line suggest relative ages that are younger or older than those of the reference scarps, respectively. 
morphology is greater than their actual age. Another factor is the presence of prominent petrocalcic horizons, which slow scarp degradation and give scarps a youthful appearance. In evaluating the competing influence of these factors on the scarps' morphology, we believe that the presence of a petrocalcic horizon has the greatest impact, and thus, the scarps tend to be have a morphology that appears younger than their true age.

The antiquity of the scarps is demonstrated by scarp-slope angles that are only $2^{\circ}-4^{\circ}$ steeper than the adjacent fan slope. The newly formed scarps probably had slope angles that were at least $20^{\circ}$ steeper than the fan slope, but the slope angles gradually decrease with increasing time. To reduce the relatively steep scarp slopes to angles within a few degrees of the fan slopes requires tens of thousand of years of erosion, especially because the petrocalcic horizon enhances the scarp-slope angle.

The field evidence indicates that the most recent surface-faulting event on the EN occurred several tens of thousands of years ago. Based on our observations of other faults in the Western U.S., we suspect that this event probably occurred at least $30-40 \mathrm{ka}$, but could be older (50-100 ka).

Range of observed total surface offset along scarps on alluvium: maximum $2.8 \mathrm{~m}$

Most of the scarp-profile data on the EN was collected for inferred single-event scarps on late Pleistocene $\mathrm{Qf}_{2}$ deposits, but we profiled one scarp (EN-7, table 4 ) near the southern end $\left(\mathrm{NE}^{1} / 4 \mathrm{sec} .29, \mathrm{~T}\right.$. $22 \mathrm{~N}$., R. 9 E.) of the EN that is probably the product of multiple events. This scarp has a surface offset of $2.8 \mathrm{~m}$, which is about three times the typical offset for single-event scarps. This scarp contains several fault strands on middle or early Pleistocene deposits (unit $\mathrm{Qf}_{1}$ of McKittrick, 1988). Our profile of this scarp (profile EN-7, appendix B) crosses several small, steep steps that are spaced 5-20 $\mathrm{m}$ apart where an indurated petrocalcic horizon is exposed at the surface; each step may mark the location of an individual fault strand. McKittrick's unit $Q f_{1}$ probably correlates with the deposits of surface 2 at Kyle Canyon, which have an age of $130 \mathrm{ka}$ (Reheis and others, 1992). If we accept this age, then the post-late Pleistocene vertical slip rate is $0.02 \mathrm{~mm} / \mathrm{yr}\left(2.8 \mathrm{~m} / 130 \mathrm{k} . \mathrm{y}\right.$.). Alternatively, if we use maximum age of $770 \mathrm{ka}$ for the $\mathrm{Qf}_{1}$ deposits, then the vertical slip rate since middle Pleistocene time is $0.004 \mathrm{~mm} / \mathrm{yr}(2.8 \mathrm{~m} / 770 \mathrm{k}$. y.).

Hoffard (1991, p. 40) reports scarps as much as $8 \mathrm{~m}$ high on Quaternary-Tertiary deposits along the EN. However, she did not specify their location, and we did not find them during our brief field investigations.

If the single, 12-m offset at the southern end of the EN is accepted as a tectonic feature (which is very uncertain), then it is likely the product of more than one earthquake. If the offset fan deposits are older than $770 \mathrm{ka}$ (unit QTf of McKittrick, 1988), then a maximum Pleistocene slip rate is about $0.015 \mathrm{~mm} / \mathrm{yr}$ (12 m/770 k. y.) at this site.

The long-term vertical slip rate on the EN is less than a few hundredths of a millimeter per year, and therecurrence time of surface-faulting earthquakes is probably several tens of thousands to perhaps hundreds of thousands of years. Surface-rupturing earthquakes have occurred on the EN during the Quaternary, but the slip rate is very low. 


\section{ASH MEADOWS FAULT ZONE (AM)}

SUMMARY: The Ash Meadows fault zone (AM) consists of discontinuous lineaments and subdued scarps that extend north-south for about $30 \mathrm{~km}$ along the eastern side of the Amargosa Desert through Ash Meadows in Nye County, Nevada, and Inyo County, California. The fault zone is informally divided into northern, central, and southern sections that individually are $6-8 \mathrm{~km}$ long, $3-6 \mathrm{~km}$ wide, and are separated by gaps of 2-5 km. Collectively, the sections extend from the area of Rock Valley Wash southward to the west flank of Shadow Mountain, which is at the northern end of the Resting Spring Range. We also include two north-trending Quaternary scarps north of Rock Valley Wash in the AM, which increases its length to about $40 \mathrm{~km}$. Scarps are present only along $25-30$ percent of this $40 \mathrm{~km}$ length.

Slickenlines in trenches reported by Donovan (1991) and antithetic scarps and grabens are direct and indirect evidence of normal slip on the AM. Surface offsets on most scarps are small (generally $\leq 1 \mathrm{~m}$ ), and the most recent surface-rupturing event is probably late Pleistocene in age. Multiple-event scarps are preserved at two locations along the southern part of the AM. The largest of two multiple-event scarps has $3.4 \mathrm{~m}$ of surface offset on middle or early Pleistocene deposits near Shadow Mountain and $1.8 \mathrm{~m}$ of surface offset on late Pleistocene alluvium. On the basis of this offset, a maximum slip rate is $0.1 \mathrm{~mm} / \mathrm{yr}$, but the small, discontinuous scarps along the remainder of the AM suggest a lower slip rate of less thar $0.01 \mathrm{~mm} / \mathrm{yr}$.

Thus, the AM is characterized mainly by numerous discontinuous lineaments and relatively few, small scarps on Quaternary deposits. The widespread distribution of these lineaments and scarps, and the location of high-yield springs along some of them suggests that they are the surface expression of a significant underlying fault zone that has been reactivated infrequently in the Quaternary. This zone is parallel to and east of the "gravity fault," a major separate intrabasin structure.

Because the age of the most recent event on each of the sections of the AM is very poorly resolved, it is impossible to determine if individual sections rupture independently or simultaneously. The rate of Quaternary deformation on this structure is very slow, and the recurrence of surface-rupturing events is probably in the range of several tens of thousands of years.

LOCATION: The AM is located along the eastern part of the Amargosa Desert in Nye County, Nevada, and Inyo County, California (fig. 13). As defined by Donovan (1991), the AM extends from an area about $14 \mathrm{~km}$ southeast of the settlement of Amargosa Valley (Lathrop Wells), Nevada, southward through Ash Meadows to about $6 \mathrm{~km}$ east of Death Valley Junction, California, near the northwestern end of the Resting Spring Range. The scarps and lineaments of the AM are generally east of Rock Valley Wash and Carson Slough. In this report, we also include two subtle, discontinuous scarps located from 3-7 km southeast of Amargosa Valley in the AM.

A recent $27-\mathrm{km}$-long seismic-reflection profile across the northern Amargosa Desert has revealed the presence of buried Tertiary subbasins in the area (Brocher and others, 1993). One of the subbasins is bounded on the east by a feature named the "gravity fault", which is a $2-\mathrm{km}$-wide, north-trending system of listric faults. Scarps and lineaments in the northern AM are in the footwall of the "gravity fault", $3-5 \mathrm{~km}$ east of its eastern strand. Thus, scarps associated with the AM appear to be unrelated to this prominent subsurface Tertiary fault.

ORIENTATION: The AM is composed of numerous, short ( $\leq 1-$ to $2-\mathrm{km}$-long) scarps and lineaments that trend between northwesterly and northeasterly (Donovan, 1991); we measured scarp trends between N. $24^{\circ} \mathrm{W}$. 


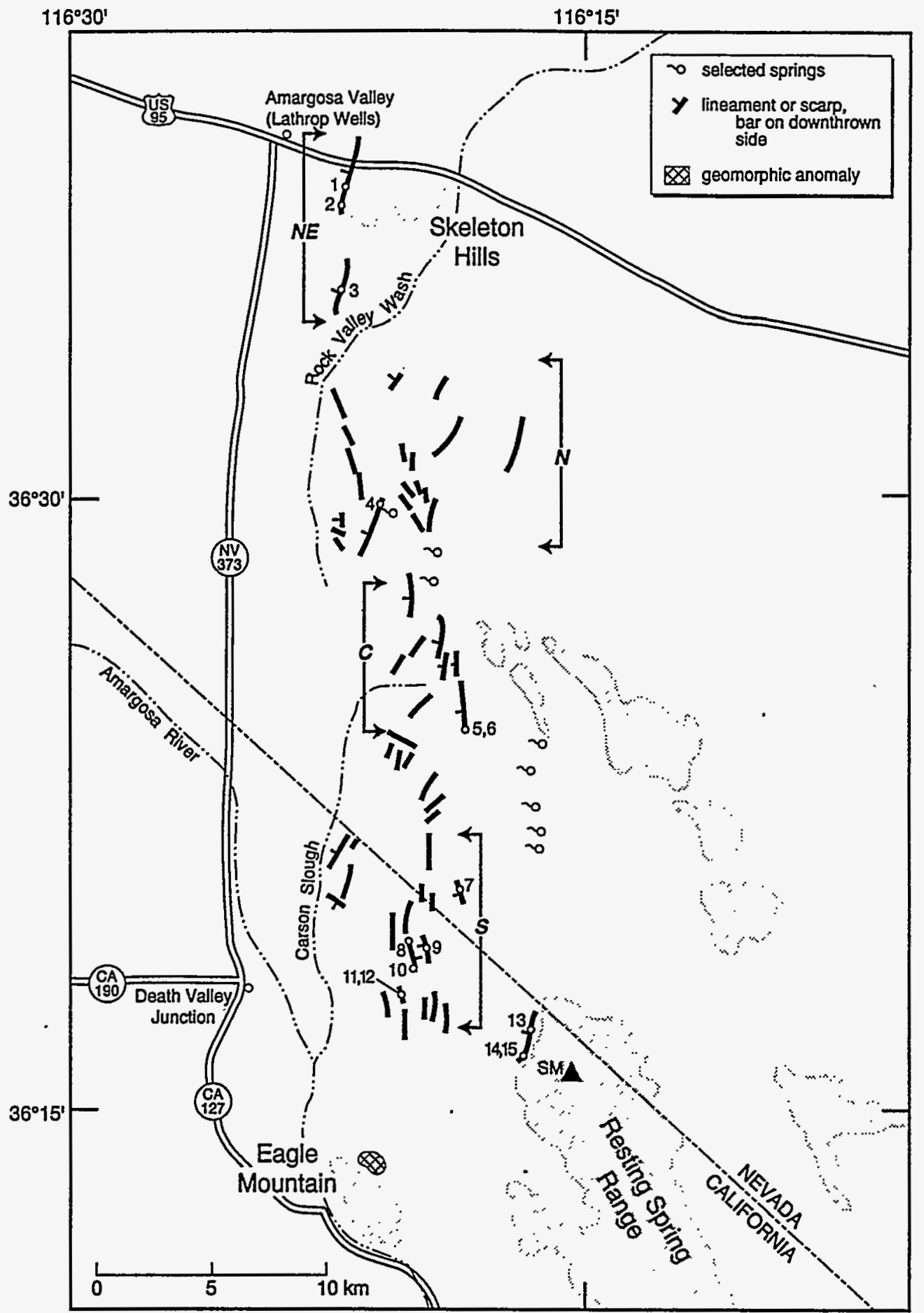

FigURE 13. Map of Quaternary fault scarps along the Ash Meadows fault zone (AM), Nye County, Nevada, and Inyo County, California (modified from Donovan, 1991; McKittrick, 1988; Piety, 1994). Areas labeled: $N$, northern; $C$, central; $S$, and southern sections of scarps are generalized after Donovan (1991). Scarps in the northern extension (NE) and near Shadow Mountain (SM) and the geomorphic anomaly near Eagle Mountain are discussed in the text. Numbered open circles indicate locations of scarp profiles; numbers correspond to the profiles listed in table 5. Extent of mostly continuous bedrock shown by half-tone fill. 
and N. $29^{\circ}$ E. Numerous aligned springs that trend N. 24 W. in Ash Meadows characterize the central section of the AM (Donovan, 1991, p. 55).

\section{LENGTH}

Length reported in Piety (1994): 30-60 km

Length of known Quaternary scarps (this study): $30.2 \mathrm{~km}$ to about $40 \mathrm{~km}$ if our proposed northern extension is included. Scarps are present along $25-30$ percent of the $40 \mathrm{~km}$ length. Length would be increased an additional $9 \mathrm{~km}$ to about $49 \mathrm{~km}$, if speculative late Quaternary deformation on the east side of Eagle Mountain is also included.

Donovan (1991) defined the AM as extending from the area near Rock Valley Wash in the northern Amargosa Desert southward to the western side of the Resting Spring Range, $4.5 \mathrm{~km}$ north-northeast of Shoshone, California. She mapped the northern $30 \mathrm{~km}$ of the fault zone in detail (from the Rock Valley area to the northern end of the Resting Spring Range), which was the limit of her aerial photography coverage. However, Donovan (1991, p. 71) states that the AM extends "at least as far south as the southern Resting Spring Range" on the basis of mapping by McKittrick (1988). Piety (1994) also included the scarps along the Resting Spring Range as part of the AM, which yields a total length of $60 \mathrm{~km}$.

Donovan (1991) divided the AM into northern, central, and southern sections. Her northern section is a zone of discontinuous, northeast- to northwest-trending scarps and lineaments in an area about $8 \mathrm{~km}$ long (north-south) and $6 \mathrm{~km}$ wide (east-west). The central section, which is centered on the springs in Ash Meadows, is separated from the northern section by a 2-km-long gap, which coincides with part of the modern valley of Carson Slough. In the central section, the zone of scarps and lineaments mapped by Donovan (1991) are about $6.5 \mathrm{~km}$ long and $3 \mathrm{~km}$ wide. The boundary between the central and southern sections is diffuse: the southernmost scarp in the central section and the northernmost scarp in the southern section are about $4-5 \mathrm{~km}$ apart. The southern section is about $7 \mathrm{~km}$ long, $4 \mathrm{~km}$ wide, and includes scarps and lineaments on the distal part of the piedmont at the northwestern end of the Resting Spring Range.

Along the western piedmont of the Resting Spring Range, McKittrick (1988) mapped a system of scattered lineaments and scarps that Donovan (1991) and Piety (1994) included in the AM (for a length of $60 \mathrm{~km}$ ). The traces of most of these features are not marked by scarps, thus their relevance to regional seismichazard assessments is uncertain. The southernmost scarps mapped by McKittrick (1988) (4.5 km northnortheast of Shoshone, California) may have been cut on the distal part of middle to early Pleistocene alluvial fans by the Amargosa River, which is less than $1 \mathrm{~km}$ valleyward (west) of the scarps. Because alluvialfan gravels in this area are interstratified with river sand, we suspect differential erosion of the loose sand in a fluvial terrace riser has steepened the scarp.

Of the traces mapped by McKittrick (1988), we found only one definite Quaternary fault scarp along the entire central and northern part of the Resting Spring Range: a conspicuous, 1.5-km-long, west-facing scarp (profiles AM-15, AM-16, AM-17 in table 5, fig. 14) on the northwest flank of Shadow Mountain (fig. 13). If we include this scarp in the AM, the length of the fault zone is the same as the $30 \mathrm{~km}$ length mapped by Donovan (1991).

We suspect that the AM may extend southward as far Eagle Mountain. An anomalous drainage pattern on the northeast side of Eagle Mountain (fig. 13) may be the result of subtle late Quaternary deformation. In this 300 -m-wide area, several $10-$ to $50-\mathrm{cm}$-deep, active, northwestward-flowing (N. $70^{\circ} \mathrm{W}$.) channels are deflected abruptly in a more northerly direction $\left(\mathrm{N} .35^{\circ} \mathrm{W}\right.$.) for several tens of meters where they return equally as abruptly to their original northwestward flow direction. The original northwestward flow direction is down the gradient of the alluvial fan, whereas the more northerly flow direction is anomalous because it is oblique to the fan gradient. In this area, creosote bushes are preferentially aligned along a 
TABLE 5. Scarp-profile data for the Ash Meadows fault zone, southern Nevada and eastern California.

[Positive surface and scarp angles denote normal geomorphic gradients; that is, toward basin center and away from sediment sources; negative angles indicate abnormal geomorphic gradients such as antithetic fault scarps. Fault section refers to informal subdivisions of fault described in text. Fault parameters as defined in figure 2: LS, lower slope angle, US, upper slope angle; SO, surface offset; SH, scarp height; $\theta$, scarp-slope angle; NA, measurement not applicable; -, no measurement.]

\begin{tabular}{clllllll}
\hline $\begin{array}{c}\text { Profile } \\
\text { No. }\end{array}$ & Fault section & $\begin{array}{l}\text { Scarp type, } \\
\text { aspect }\end{array}$ & LS & US & $\begin{array}{c}\text { SO } \\
(\mathrm{m})\end{array}$ & $\begin{array}{c}\text { SH } \\
(\mathrm{m})\end{array}$ & $\theta$ \\
\hline AM-1 & Northern.extension & Normal, W & $1.2^{\circ}$ & $1.2^{\circ}$ & 0.5 & 1.0 & $2.9^{\circ}$ \\
AM-2 & Northern extension & $\begin{array}{l}\text { Normal with } \\
\text { graben, W }\end{array}$ & $0.8^{\circ}$ & $1.0^{\circ}$ & 0.6 & 0.9 & $2.7^{\circ}$ \\
AM-3 & Northern extension & Normal, W & $0.7^{\circ}$ & $0.5^{\circ}$ & 1.4 & 1.8 & $2.8^{\circ}$ \\
AM-4 & Northern & Antithetic, NW & $0.5^{\circ}$ & $0.5^{\circ}$ & 0.2 & 0.2 & $-2.8^{\circ}$ \\
AM-5 & Central & Normal, W & $1.1^{\circ}$ & $1.1^{\circ}$ & 0.4 & 1.6 & $1.5^{\circ}$ \\
AM-6 & Central & Normal, W & $0.0^{\circ}$ & $0.1^{\circ}$ & 0.7 & 0.8 & $2.1^{\circ}$ \\
AM-7 & Southern & Normal, W & $0.5^{\circ}$ & $0.5^{\circ}$ & 0.4 & 0.6 & $1.5^{\circ}$ \\
AM-8 & Southern & Antithetic, E & $1.2^{\circ}$ & $1.0^{\circ}$ & 0.4 & $\mathrm{NA}$ & $-0.2^{\circ}$ \\
AM-9 & Southern & Normal, W & $1.4^{\circ}$ & $2.1^{\circ}$ & 0.7 & 1.6 & $3.3^{\circ}$ \\
AM-10 & Southern & Antithetic, E & - & $1.1^{\circ}$ & - & $>1.9$ & $-4.0^{\circ}$ \\
AM-11 & Southem & Antithetic, E & $1.9^{\circ}$ & $1.6^{\circ}$ & 0.6 & $\mathrm{NA}$ & $-0.7^{\circ}$ \\
AM-12 & Southern & Antithetic, E & $1.3^{\circ}$ & $1.2^{\circ}$ & 0.4 & $\mathrm{NA}$ & $0.4^{\circ}$ \\
AM-13 & Southern & Normal with & $3.5^{\circ}$ & $3.8^{\circ}$ & 1.5 & 3.2 & $7.1^{\circ}$ \\
& & graben, W & & & & & \\
AM-14 & Southern & Normal, W & $7.1^{\circ}$ & $7.0^{\circ}$ & 3.4 & 6.5 & $17.5^{\circ}$ \\
AM-15 & Southern & Normal, W & $6.9^{\circ}$ & $6.5^{\circ}$ & 1.8 & 3.5 & $15.6^{\circ}$ \\
\hline
\end{tabular}

N. $30^{\circ} \mathrm{W}$. trend. This anomalous drainage pattern may reflect young deformation that has affected small, active channels along a 300 -m-long zone.

We extend the AM north of the Rock Valley Wash area, which increases it length by about $10 \mathrm{~km}$. This extension is based on the presence of low, north-trending fault scarps (profiles AM- 1 through AM- 3 in table 5) on the southwest and northwest sides of the Skeleton Hills. Their northerly trend and their down-to-the-west throw indicate that these scarps are part of the AM rather than the Rock Valley fault zone (RV). The scarps trend between N. $3^{\circ} \mathrm{E}$. and N. $10^{\circ} \mathrm{E}$., whereas scarps associated with the RV trend N. $55^{\circ} \mathrm{E}$. Furthermore, the down-to-the-west throw is consistent with the throw direction of AM, whereas RV scarps generally have variable throw directions because their sense of slip is dominantly left-lateral.

STYLE OF FAULTING: Normal, down to west

Slickenlines in trenches (Donovan, 1991) and other evidence summarized by Piety (1994) indicate normal dip slip on the AM. Antithetic scarps and grabens at several locations support normal slip.

\section{DISPLACEMENT AND AGE}

Range of observed surface offset and scarp height representing the youngest movement: $0.2-1.8 \mathrm{~m}$ (surface offset); 0.2-3.5 m (scarp height)

Scarp height and surface offset measurements range widely along the fault zone, but surface offsets are generally less than $1 \mathrm{~m}$; exceptions are a scarp at the northern end with $1.4 \mathrm{~m}$ of surface offset (profile AM-3 


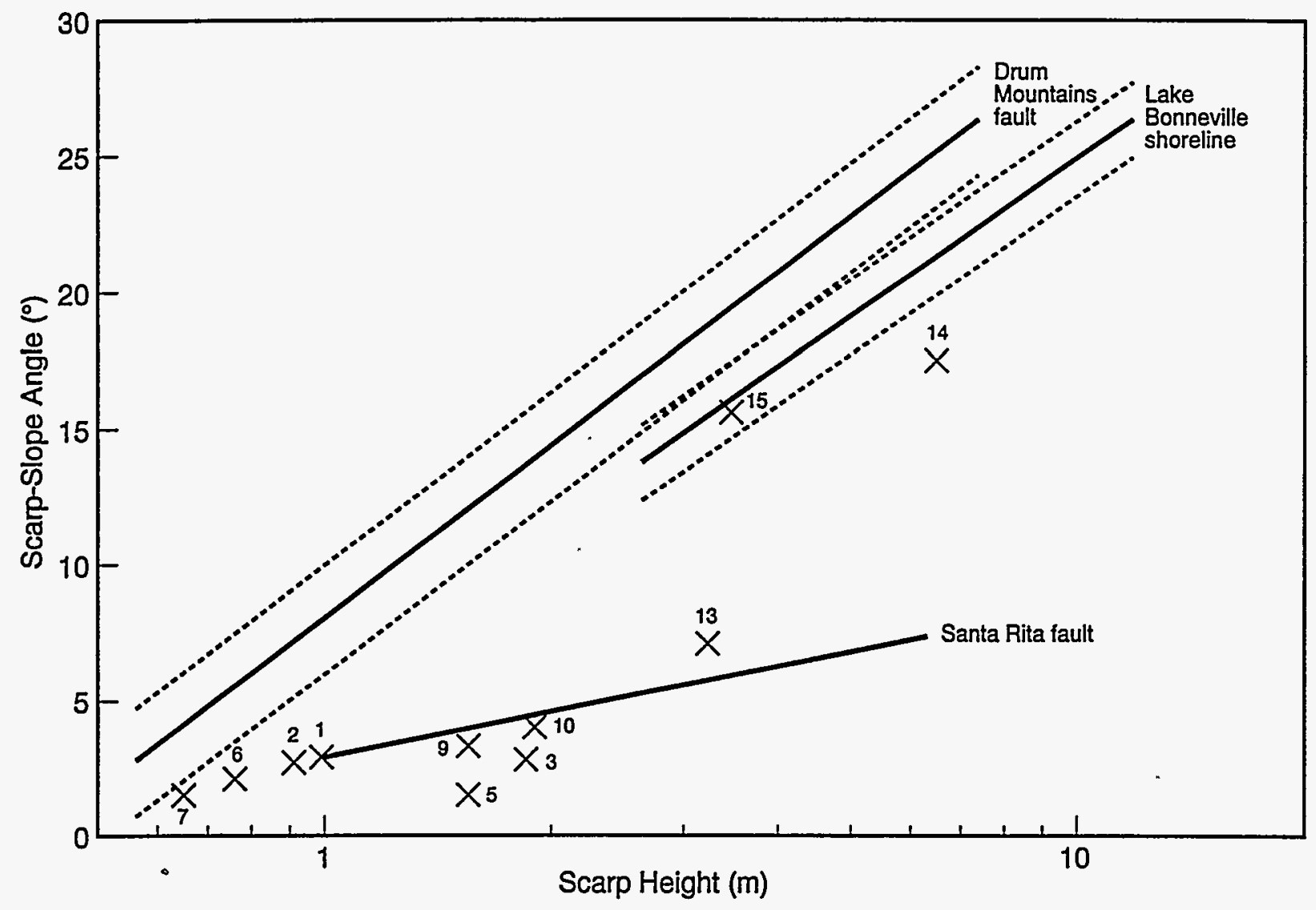

FiguRE 14. Plot of scarp-height--slope-angle values for scarp on alluvium along the Ash Meadows fault zone (AM). Site numbers shown in figure 13 and table 5 . Profile 4 is not plotted because of its small size, and profiles 8,11 , and 12 are not plotted because they lack scarp height values. Solid lines, regression lines for reference scarps; dotted lines, 1- limits for regressions. Lake Bonneville shoreline scarp (about $15 \mathrm{ka}$; Machette, 1989) and Drum Mountains fault scarp (about $10 \mathrm{ka}$; Crone, 1983) both from Bucknam and Anderson (1979); Santa Rita fault scarp (estimated age about $100 \mathrm{ka}$; Pearthree and Calvo, 1987). Points that plot above or below the 1- $\sigma$ limits of a regression line suggest relative ages that are younger or older than those of the reference scarps, respectively. The fault zone is divided into sections following to Donovan (1991); see text for details.

in table 5) and a scarp at the southern end with as much as $3.4 \mathrm{~m}$ of surface offset (profiles AM-13 through AM-15 in table 5). We consider all scarps with maximum surface offsets of about $1 \mathrm{~m}$ to record single surface-rupturing events.

\section{Estimated age of most recent surface-faulting event: late Pleistocene}

The age of the most recent event on the AM is uncertain. The morphology of scarps formed on gravelly alluvium on the northern extension (profiles AM-1 through AM-3 in table 5) can be compared to shoreline scarps of Lake Bonneville as a general guide to their age. Morphologically, these scarps at the northern end are more degraded and subdued than the Lake Bonneville scarps, which suggests that the faulting that produced these scarps is older than latest Pleistocene (fig. 14). These scarps are probably more than $30-40 \mathrm{ka}$.

We examined many of the tonal lineaments, linear reaches of drainages, and scarps along channel margins mapped by Donovan (1991) in the northern section, but profiled only one scarp (AM-4 in table 5). Many other reported high scarps, commonly about 1-1.5 $\mathrm{m}$ high, coincide with the boundary between fine-grained Pliocene sediment and Pliocene sediment capped by a thin veneer of Quaternary gravel. These 
linear escarpments are probably structurally controlled and probably coincide with faults in the Pliocene deposits. Resistant tufa beds are common in the Pliocene deposits and, where the tufa is fractured and jointed, differential erosion probably forms scarps.

In some areas, resistant tufa beds cap gently sloping, planar surfaces that are locally offset by faults (for example, a N. $24^{\circ}$ W.-trending scarp in $\mathrm{SE}^{2} / 4 \mathrm{sec} .4, \mathrm{~T}$. $17 \mathrm{~S}$., R. 50 E., Skeleton Hills $7.5^{\prime}$ quadrangle). Locally, the surfaces are mantled by unfaulted eolian sand, which is probably of Holocene age. Scarps on these tufacapped piedmonts are prominent on aerial photographs where they mark a sharp boundary between parts of the piedmont that have little or no eolian sand and adjacent parts that have abundant sand. These boundaries look like faults on aerial photographs because they mark sharp tonal contrasts. They probably reflect minor differences in vegetation density, which subsequently controls the capture of sand that moves across the scarp. Regardless of their origin, the low heights and gentle slopes of the scarps (profile AM-4 in table 5) indicate an age of at least several tens of thousands of years. The scarps could be much older if it is the relatively resistant tufa that is preserving their youthful morphologic expression.

The age of the most recent event on the central section is poorly constrained. Donovan (1991) notes that some scarps are on late Pleistocene alluvium, but many are at the boundary between Quaternary-Pliocene lacustrine sediment and Quaternary alluvium. Thus, correlative deposits are not present on both sides of the scarps and thus cannot be used to constrain the timing or amount of faulting. The ages of the Quaternary deposits in the central section are not well documented. Donovan (1991) reports the age of the faulting as late Pleistocene because deposits thought to be late Pleistocene in age are displaced in trench exposures (trenches TR3 and TR4 of Donovan, 1991). The late Pleistocene age designation seems realistic based the description of the soil exposed in Donovan's trench TR4.

The majority of the features included in the southern section (Donovan, 1991) are channel-edge scarps and vegetation and tonal lineaments, but this section also contains five scarps that are $0.2-1.0 \mathrm{~km}$ long. We profiled four of the scarps in this section, but the fifth is probably a fluvial scarp. Two of the scarps (profiles AM-11 and AM-12 in table 5) are on late Pleistocene alluvium that has a 3- to 5-cm-thick, sandy Av horizon, a 10- to 20-cm-thick sandy Bw or Bt horizon, and a Btk horizon (stage II soil carbonate morphology) about 24-30 cm below the surface. On the basis of this soil development, the surface is probably late Pleistocene in age. The subdued morphology of these scarps suggests that they are older that the latest Pleistocene shoreline of Lake Bonneville.

The largest single-event scarp in the AM is on the northwestern piedmont of Shadow Mountain (AM-15 in table 5). The scarp is high $(3.5 \mathrm{~m})$ because it is formed on a steep $\left(\geq 6.5^{\circ}\right)$ fan surface, but its surface offset $(1.8 \mathrm{~m})$ is not unusually large compared to single-event scarps on historic normal faults that are at least $20 \mathrm{~km}$ long (Wells and Coppersmith, 1994). This scarp is on deposits mapped by McKittrick (1988) as late or middle Pleistocene $\left(\mathrm{Qf}_{2}\right)$. Its morphology suggests an age similar to that of the Lake Bonneville shoreline scarp.

Range of observed total surface offset along scarps on alluvium: $0.2 \mathrm{~m}-3.4 \mathrm{~m}$

Scarps along the AM are generally small; the largest ones are in Donovan's (1991) southern section and in the Shadow Mountain area. In this part of the AM, there is evidence of multiple surface-rupturing events on east-facing antithetic scarps in secs. 6 and 16, T. 25 N., R. 6 E., and on a west-facing scarp in NE $1 / 4$ sec. 25 , T. 25 N., R. 6 E. (both in Bole Spring 7.5' quadrangle). At the first location, scarps are present on alluvial surfaces of three different ages. The scarp on late Pleistocene deposits has a surface offset of 0.4-0.6 m (AM11 and $A M-12$ in table 5, fig. 15). On a different antithetic scarp about $1 \mathrm{~km}$ to the north, the surface offset is $0.4 \mathrm{~m}$ (AM-8) on a deposit of probable early late Pleistocene or middle Pleistocene age. Southward, this scarp is on an older, partially preserved alluvial surface of probable middle Pleistocene age (AM-10) (because 


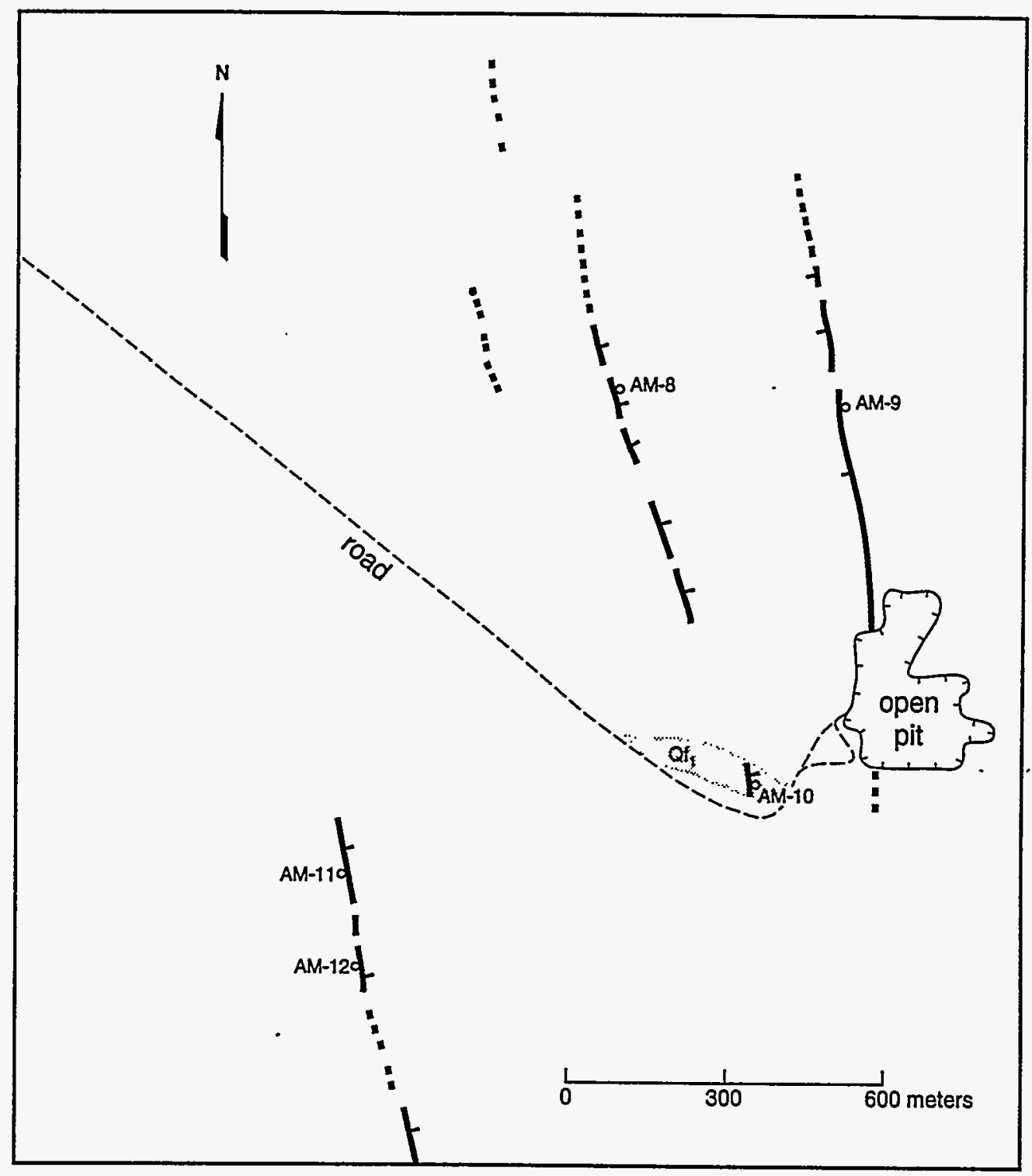

FIguRE 15. Detailed map of prominent scarps along Ash Meadows fault zone (AM) in NE1/4 sec. 25, T. 25 N., R. 6 E., Inyo County, California (Bole Spring $7.5^{\prime}$ quadrangle). Open circles show profile sites; profile numbers correspond to the profiles listed in table 5. The deposit mapped as $\mathrm{Qf}_{1}$ is inferred to be middle Pleistocene, and the scarp on it is larger than scarps on the adjacent deposits (not mapped in detail) that are thought to be late Pleistocene in age.

this scarp is poorly preserved and erosionally modified, profile AM-10 does not traverse the entire scarp, but does show the scarp's general morphology and offers a perspective of its height).

At the second location (Shadow Mountain), a single-event scarp is formed on late or middle Pleistocene Qf ${ }_{2}$ deposits (McKittrick, 1988), and a multiple-event scarp is formed on Qf deposits, which McKittrick assigns a middle or early Pleistocene age. The $Q f_{2}$ deposits probably correlate with deposits that underlie surface 3 at Kyle Canyon (Sowers, 1986; Reheis and others, 1992), and the Qf deposits probably correlate with those that underlie surface 2. Surface 3 deposits have been dated by ${ }^{14} \mathrm{C}$ at $10-15 \mathrm{ka}$ and by the uranium-series method at $47 \pm 20$ and $76 \pm 6 \mathrm{ka}$, and they appear to be a time-transgressive late Pleistocene alluvial sequence in which the age of the deposit increases toward the head of the fan (Reheis and others, 1992). Surface 2 deposits at Kyle Canyon are considered to be $130 \mathrm{ka}$ (Reheis and others, 1992). 
At the Shadow Mountain site, the single-event scarp has a surface offset of $1.8 \mathrm{~m}$ (AM-15), and the multiple-event scarp has a surface offset of $3.4 \mathrm{~m}$ (AM-14). If correlations with the Kyle Canyon deposits are correct, then the single-event scarp could be on deposits that are as young as 10-15 ka, although we suspect that their age in this area is probably at least 30-50 ka because the deposits have a well-developed desert pavement and well-varnished clasts. The morphology of the single-event scarp indicates that it is comparable to Lake Bonneville scarps (fig. 14).

The penultimate event in this area predates deposition of the $\mathrm{Qf}_{2}$ deposits, which we assume ended 30-50 ka. If we use these constraints, then the maximum late Pleistocene slip rate is $0.1 \mathrm{~mm} / \mathrm{yr}$ $(3.4 \mathrm{~m} / 30 \mathrm{k}$. y.). However, based on the morphology of scarp AM-13, which may be a single-event scarp from the penultimate event, the age of this older event could easily be $100 \mathrm{ka}$. Thus, the recurrence time between events is at least $15-20 \mathrm{k}$. y. (time between $30 \mathrm{ka}$ and most recent event which produced Lake Bonneville-like scarp), and more likely is greater than $50 \mathrm{k}$. y. (if penultimate event is about $100 \mathrm{ka}$ and most recent event is latest Pleistocene).

Slip-rate estimates from other places along the AM are plagued with similarly large uncertainties because the ages of Quaternary deposits are poorly known and because correlative deposits are rarely preserved on both sides of scarps. If the estimates that we offer for the Shadow Mountain scarps apply to the entire zone, then the long-term slip rate is no more than $0.1 \mathrm{~mm} / \mathrm{yr}$ and is more likely an order of magnitude less $(\sim 0.01 \mathrm{~mm} / \mathrm{yr})$. The rounded, small scarps along the AM suggest that a slip rate of less than $0.01 \mathrm{~mm} / \mathrm{yr}$ is a more realistic estimate.

The widespread distribution of the lineaments and scarps that define the AM suggests that they identify the location of a significant underlying fault zone that has been reactivated infrequently in the Quaternary. Because the age of the most recent event on each of the sections is very poorly resolved, it is impossible to determine if individual sections rupture independently or simultaneously. The rate of Quaternary deformation on this structure is very slow, and the recurrence of surface ruptures is probably in the range of several tens of thousands of years. 


\section{ROCK VALLEY FAULT ZONE (RV), SOUTHWESTERN EXTENSION}

SUMMARY: Several authors have suggested that the Rock Valley fault zone (RV) extends southwest into the area of our study. Fault scarps that may mark this southwestern extension trend N. $55^{\circ}$ E. across the Amargosa Desert north of Ash Meadows. The most continuous part forms a 7- $\mathrm{km}$-long fault trace that trends N. $62^{\circ}$ E. across Nevada Highway 29 about $0.8 \mathrm{~km}$ north of the Amargosa Valley Post Office. Other similarly oriented scarps are present to the northeast, primarily south of the Striped Hills. The entire RV has a N. $50^{\circ}$ E. orientation over its $65 \mathrm{~km}$ length, which extends from Amargosa Valley northeast to Frenchman Flat. The RV is inferred to be primarily left-lateral, but there is no direct evidence for the amount or direction of lateral slip along the part of the fault we studied. Also unknown are the amount of surface offset and the resulting scarp heights from the most recent surface-faulting event, which is estimated to be late Pleistocene in age. Scarps along the southwestern extension of the RV have 0.3-1.3 m of vertical offset in Quaternary alluvium, but the amount of lateral slip is unknown; thus, meaningful slip rates cannot be calculated.

LOCATION: This possible southwestern extension of the RV trends west-southwest into the Amargosa Desert from its type locality in Rock Valley (fig. 16). Its northeastern end is problematic (see Piety, 1994). Donovan (1991) shows it continuing about $5 \mathrm{~km}$ northeast of U.S. Highway 95 with traces both north and south of the Skeleton Hills (beyond the area shown in fig. 17). Restricted access prevented us from confirming the location or age of scarps north of the highway. The most continuous trace of the fault crosses $\mathrm{Ne}$ vada Highway 29 about $0.8 \mathrm{~km}$ north of the Amargosa Valley, Nevada, Post Office (fig. 16). The fault is marked by Quaternary scarps from about $2.8 \mathrm{~km}$ west of Nevada Highway 29 (W. edge of sec. 34, T. 16 S., R. 49 E., South of Amargosa Valley 7.5' quadrangle) northeastward to the center of sec. 36, T. 15 S., R. 50 E. (Skeleton Hills 7.5' quadrangle), where it crosses Rock Valley Wash at an acute angle (fig. 17). Scarps in the Amargosa Desert have many trends. Those believed to be associated with the RV are defined on the basis of a northeast-trending orientation. Donovan (1991) used this rational to include some features within and north of the Striped Hills as part of the RV; however, we did not study these features. South of the Skeleton Hills, faults that may be part of the RV form a wide, subdued graben between uplifted blocks of alluvium that divert the drainage of Rock Valley Wash from a southerly (down-fan) course to a southwesterly course (fig: 17).

ORIENTATION: N. $55^{\circ} \mathrm{E}$.

The southwestern extension of the RV has a N. $55^{\circ}$ E. orientation. The mostly continuous, $7-\mathrm{km}-\mathrm{long}$ trace of the fault adjacent to Nevada Highway 29 trends N. $62^{\circ}$ E., whereas the portion of the fault south of the Skeleton Hills has a N. $55^{\circ}$ E. orientation. A series of kilometer-scale left steps gives the RV a N. $50^{\circ} \mathrm{E}$. orientation from Amargosa Valley to Frenchman Flat (within the Nevada Test Site).

\section{LENGTH}

Length reported in Piety (1994): 32-65 $\mathrm{km}$ (RV and its southwest extension)

Length of known Quaternary scarps (this study): $16.0 \mathrm{~km}$ in Amargosa Valley (includes discontinuous scarps from west of Nevada Highway 29 to about $2 \mathrm{~km}$ south of U.S. Highway 95)

Several authors (see Piety, 1994) have suggested that the RV extends southwest into the area of our study. The RV has been described as being $32-65 \mathrm{~km}$ in length depending on whether or not this extension is included. We found evidence for Quaternary movement along many parts of the fault in the Amargosa 


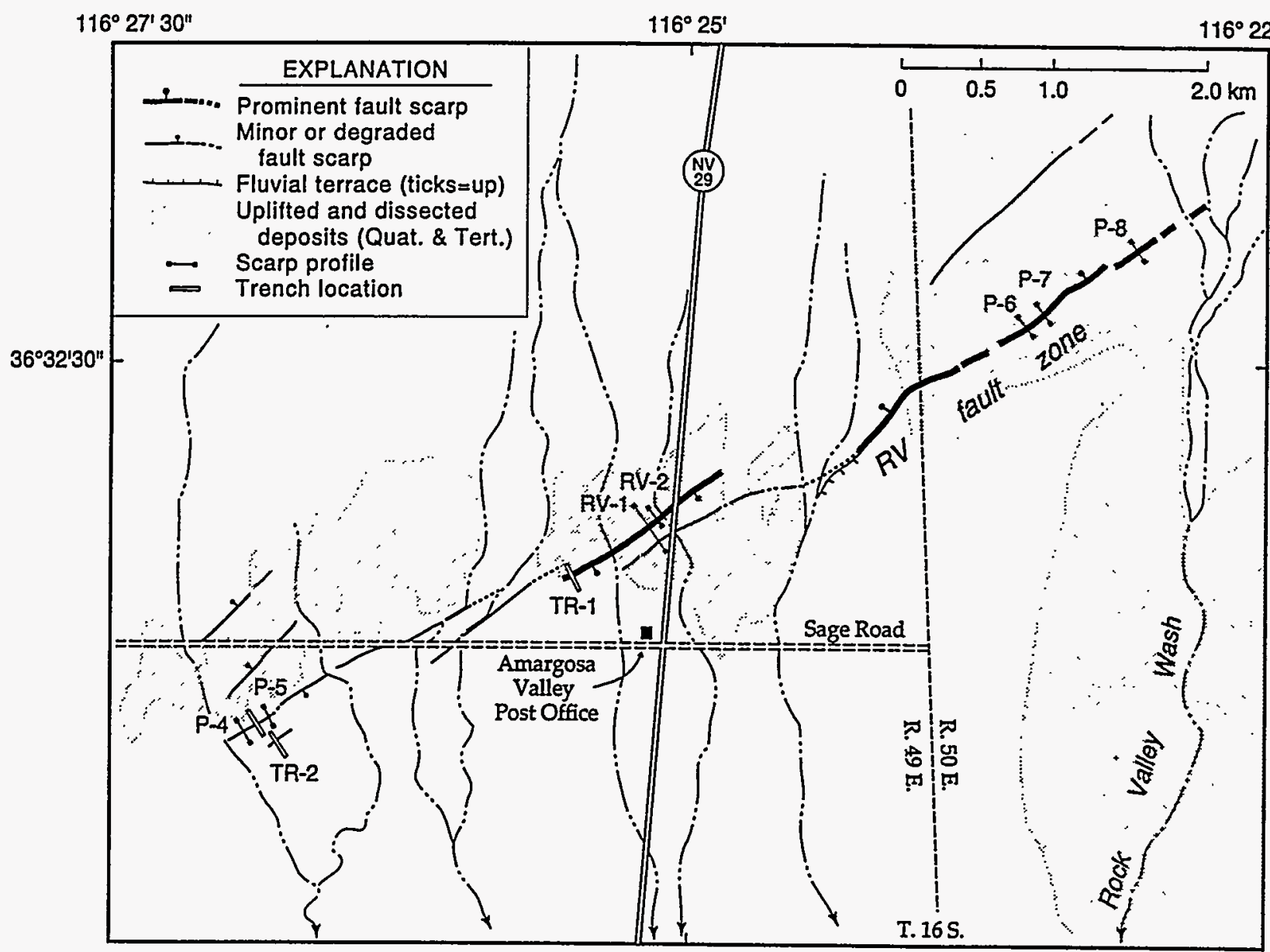

FiguRE 16. Map of the southwest extension of the Rock Valley fault zone (RV) adjacent to Nevada Highway 29 showing associated geographic and cultural features. Scarp profiles correspond to those listed in table 6 . Trench locations are from Donovan (1991).

Desert. In addition, along the projection of the RV there are fault-line scarps, deflected or incised stream channels, and tonal lineations that suggest at least $16 \mathrm{~km}$ of Quaternary movement. The main RV (Rock Valley fault proper in Piety, 1994) extends from the Specter Range northeast through Rock Valley and as far east as Frenchman Flats, a distance of $32 \mathrm{~km}$. If the RV extends from the Specter Range southwest to sec. 33 T. 16 S., R. 49 E., the total fault length is about $65 \mathrm{~km}$ (Piety, 1994).

STYLE OF FAULTING: Primarily strike slip (inferred left lateral)

Evidence for left-lateral slip and amounts of displacement are documented in studies of the fault in its type area in Rock Valley. There, Yount and others (1987) argued for an unknown amount of left-lateraloblique (north-side down) offset of latest Pleistocene deposits. Some streams that cross the fault in Amargosa Valley (fig. 16) show an apparent right-lateral sense of offset, but other streams, both larger and smaller, do not. Along the southwestern extension of the RV we found no direct evidence for the amount or direction of lateral slip. Indirect evidence for left-lateral strike-slip faulting comes from a right-stepping pattern of scarps (see fig. 16). Donovan (1991) argues for a left step in the fault in order to connect the two areas of northeast-trending fault scarps shown in figures 16 and 17. The RV has a small amount of down-to-thesouth throw near and west of Nevada Highway 29 and a small amount of down-to-the-north throw east of Nevada Highway 29, a pattern typical of strike-slip faults. "Scarp profiles measured by Donovan" (1991) 


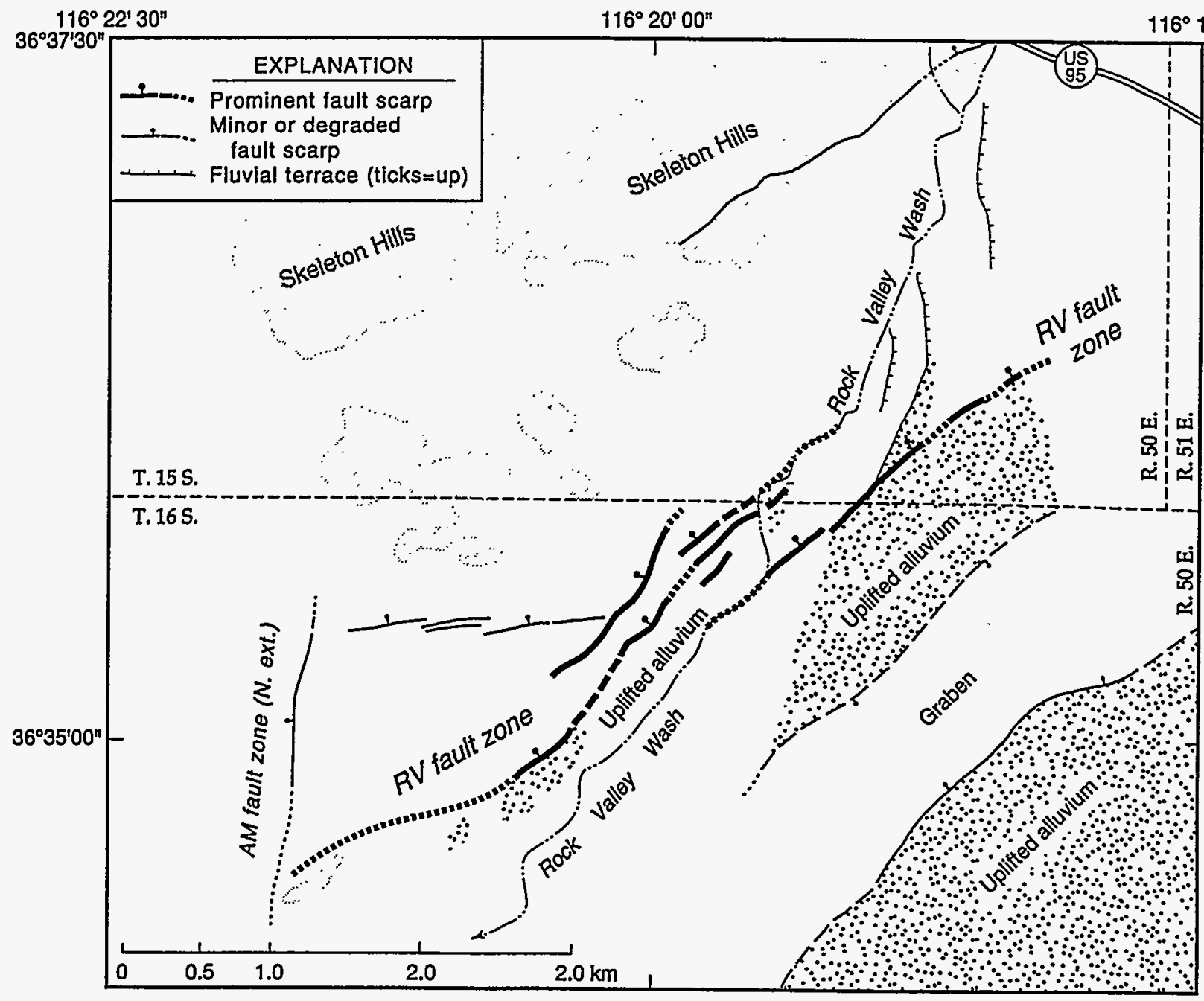

Figure 17. Map of the southwest extension of the Rock Valley fault zone (RV) south of the Skeleton Hills showing selected geographic and cultural features. Extent of mostly continuous bedrock shown by half-tone fill, uplifted alluvium shown by stipple pattern.

and this study (table 6) indicate a maximum vertical surface offset of about $1 \mathrm{~m}$ and scarp heights of $3.3 \mathrm{~m}$ or less. South of the Skeleton Hills (fig. 17), the majority of Quaternary fault scarps are associated with downto-the-north throw on the RV.

\section{DISPLACEMENT AND AGE}

Range of observed surface offset and scarp height representing the youngest movement: not documented

We made no definitive measurements of scarp heights or offsets in this study. Nevertheless, the 370-m-long scarp profile measured just west of Nevada Highway 29 (profile RV-1 in appendix B) shows the remarkable width of the graben at this site and implies a long and complex history of movement. The southeast-facing scarp is about $3.3 \mathrm{~m}$ high, yet it only relates to about $0.5 \mathrm{~m}$ of net vertical offset of the surface (profile RV-1 in table 6, fig. 18). This disparity in height versus offset (1:6.6) suggests that the scarp is related to multiple faulting events and a wide zone of deformation. The most recent faulting event may have caused a slight steepening near the base of the main scarp, as noted by a $4.5^{\circ}-4.6^{\circ}$ slope angle on the broader, more gently inclined scarp (generally $2.5^{\circ}-3.8^{\circ}$, fig. 18; see profiles RV-1 and RV-2, table 6). However, 
TABLE 6. Scarp-profile data for the southwestern extension of the Rock Valley fault zone (RV), southern Nevada.

\begin{tabular}{|c|c|c|c|c|c|c|c|}
\hline $\begin{array}{l}\text { Profile } \\
\text { No. }\end{array}$ & Fault section & $\begin{array}{l}\text { Scarp type, } \\
\text { aspect }\end{array}$ & LS & us & $\begin{array}{l}\mathrm{SO} \\
(\mathrm{m})\end{array}$ & $\begin{array}{l}\text { SH } \\
(m)\end{array}$ & $\theta$ \\
\hline$P-4 \ddagger$ & $\begin{array}{l}\text { Southwestern } \\
\text { extension }\end{array}$ & $\begin{array}{l}\text { Oblique-normal, } \\
\text { SE }\end{array}$ & $<1^{\circ}$ & $<1^{\circ}$ & $0.8 e$ & - & $14^{\circ}$ \\
\hline$P-5 \ddagger$ & $\begin{array}{c}\text { Southwestern } \\
\text { extension }\end{array}$ & $\begin{array}{l}\text { Oblique-normal, } \\
\mathrm{SE}\end{array}$ & $<1^{\circ}$ & $<1^{\circ}$ & $0.7 e$ & - & $8^{\circ}$ \\
\hline$R V-1$ & $\begin{array}{l}\text { Southwestern } \\
\text { extension }\end{array}$ & $\begin{array}{l}\text { Oblique-normal } \\
\text { with graben, SE }\end{array}$ & $1.1^{\circ}$ & $1.0^{\circ}$ & 0.5 & 3.3 & $4.6^{\circ}$ \\
\hline RV-2 & $\begin{array}{l}\text { Southwestern } \\
\text { extension }\end{array}$ & $\begin{array}{l}\text { Oblique-normal } \\
\text { with graben, SE }\end{array}$ & $1.2^{\circ}$ & $1.1^{\circ}$ & $>0.9$ & $>1.2$ & $4.5^{\circ}$ \\
\hline $\mathrm{P}-6 \ddagger$ & $\begin{array}{l}\text { Southwestern } \\
\text { extension }\end{array}$ & $\begin{array}{l}\text { Oblique-normal, } \\
\mathrm{NW}\end{array}$ & $<1^{\circ}$ & $<1^{\circ}$ & $0.3 e$ & - & $\sigma^{\circ}$ \\
\hline $\mathrm{P}-7 \ddagger$ & $\begin{array}{l}\text { Southwestern } \\
\text { extension }\end{array}$ & $\begin{array}{l}\text { Oblique-normal, } \\
\text { NW }\end{array}$ & $<1^{\circ}$ & $<1^{\circ}$ & $0.5 e$ & - & 5 \\
\hline$P-8 \ddagger$ & $\begin{array}{l}\text { Southwestern } \\
\text { extension }\end{array}$ & $\begin{array}{l}\text { Oblique-normal, } \\
\text { NW }\end{array}$ & $<1^{\circ}$ & $<1^{\circ}$ & $1.1 e$ & - & 6.5 \\
\hline
\end{tabular}

the steepening also could be related to resistant units that outcrop elsewhere along the scarp; for example, Donovan (1991) measured scarp-slope angles of $8^{\circ}$ and $14^{\circ}$, which are caused by resistant petrocalcic horizons exposed in and near her trench TR-2 (fig. 16).

Estimated age of most recent surface-faulting event: probably late Pleistocene

Although Donovan (1991) inferred offset of Holocene deposits (Q1s and Q1c of Swadley, 1983) in our study area, we found no compelling evidence that the most recent fault movement is Holocene. Donovan's age estimate appears to be based on unit correlations and inferences about groundwater levels and climatic considerations rather than from dating faulted deposits. For example, Donovan (1991) states that the petrocalcic horizon in trench TR-1 (unit TR1C), which contains fractures, is most likely part of unit Q1a of Swadley (1983) and thus is Holocene. From our experience and published studies of the rates of calcic soil formation (Machette, 1985), it appears that most petrocalcic horizons (stage IV or more advanced) require considerably more time than $10 \mathrm{k}$. y. to develop-perhaps $100 \mathrm{k}$. y. is a more reasonable estimate. The scarp's morphology is not suggestive of a significant $(>0.5 \mathrm{~m})$ amount of young vertical motion, nor is there evidence for a consistent pattern of lateral slip in the geomorphology or stream patterns that would be indicative of young faulting. Donovan (1991) noted scarp-slope angles of $8^{\circ}$ and $14^{\circ}$, which seem to be related to resistant petrocalcic horizons rather than young faulting. In addition, many of the scarps formed along the fault are on older (Tertiary?) deposits, and thus may reflect differential erosion along the fault. Although the discontinuous pattern of faulting might be explained by young lateral motion (right steps), it may also be a result of fluvial erosion since the most recent faulting event. Thus, we conclude that the most-recent faulting event along the southwestern extension of the RV is probably late Pleistocene in age.

Range of observed total surface offset along scarps on alluvium: $0.3-1.3 \mathrm{~m}$ vertical (estimated); amount of lateral component unknown

Scarp profiles by Donovan (1991) and this study indicate a maximum vertical surface offset of about $1.1 \mathrm{~m}$ (profile $\mathrm{P}-8$, in table 6) and a scarp height of $3.3 \mathrm{~m}$ (profile RV-1 in table 6) where a graben that crosses 


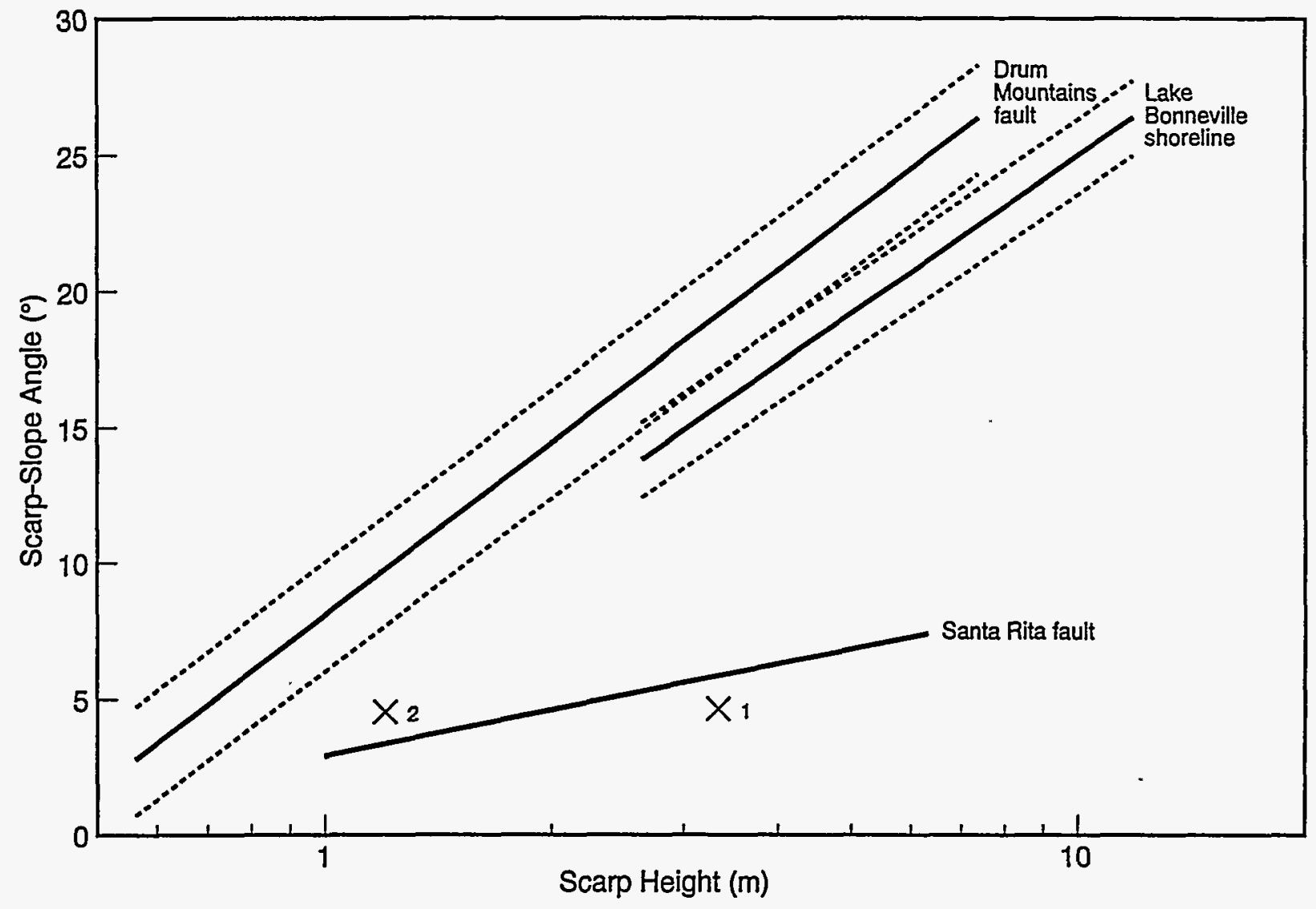

FiquaE 18. Plot of scarp-height-slope-angle values for scarps on the southwest extension of the Rock Valley fault zone (RV). Numbers refer to scarp profiles from this study in table 6 . Solid lines, regression lines for reference scarps; dotted lines, $1-\sigma$ limits for regressions. Lake Bonneville shoreline scarp (about $15 \mathrm{ka}$; Machette, 1989) and Drum Mountains fault scarp (about $10 \mathrm{ka}$; Crone, 1983) both from Bucknam and Anderson (1979); Santa Rita fault scarp (estimated age about $100 \mathrm{ka}$; Pearthree and Calvo, 1987). Points that plot above or below the 1- $\sigma$ limits of a regression line suggest relative ages that are younger or older than those of the reference scarps, respectively.

Nevada Highway 29 is well developed. Most other fault scarps associated with the fault have less than $1 \mathrm{~m}$ of vertical surface offset. Donovan (1991) notes that much of the fault has scarps developed on Quaternary and or Tertiary lake deposits (QTId), so surface offsets across these scarps are too old to be useful for estimates of offset or slip rate. However, at profile sites RV-1 and RV-2 (fig. 16), the scarp is formed on a thin ( $<1 \mathrm{~m}$ ) mantle of alluvial gravel that lies on older deposits of probable Tertiary age; thus, it may reflect the total vertical offset since the gravel was deposited. Soils in the gravel have a thick Av horizon that is being engulfed by the underlying Bt horizon and a stage III calcic horizon with thick coatings of carbonate on clasts, all of which suggest the soil is probably late to middle Pleistocene in age (100-200 ka?). South of the Skeleton Hills, most of the fault scarps face north, and thus have been subject to fluvial erosion from southward-flowing streams. Because many of these scarps are larger (5-10 $\mathrm{mhigh})$ than those to the southwest, they suggest both multiple-faulting events, some with more net vertical offset than other scarps along the RV. However, because of a lack of exposures, we cannot be sure that the same deposits are present on both sides of the fault, and thus the true amounts of vertical surface offset are not well constrained. Meaningful slip rates across the southwestern extension of the RV cannot be calculated without better data on offset per event and recurrence times. 


\section{SUMMARY}

Quaternary faults in the California-Nevada border area south and southeast of Yucca Mountain have diverse orientations and senses of slip consistent with their location along or near the junctures between structurally contrasting sections of the Walker Lane belt. Because issues of possible interconnectedness or mechanical interaction between these structures may have relevance to the integrity of the Yucca Mountain site, five of these faults in the Amargosa Valley-Stewart Valley-Pahrump Valley-area were studied as a group.

Scarps are sparse along the PSV. In Pahrump and Stewart Valleys, scarps marking the surface trace of unequivocal late Quaternary surface-faulting events were found along only $18.5 \mathrm{~km}$ of the estimated $50 \mathrm{~km}$ of trace length of the PSV. Most scarps are formed on easily erodable silty playa deposits, making them difficult to evaluate in terms of age or possible multiple-event history. Based on a qualitative assessment of a 2-m-high scarp that is inferred to have formed from a single surface-faulting event, the most recent surfacefaulting event may be as young as middle Holocene. Scarps in Stewart Valley are as much as $5 \mathrm{~m}$ high, but are in an area with abundant evidence of fluvial modification, so the heights may be unreliable for estimating the surface offset. Scarps in southern Pahrump Valley indicate as much as $15 \mathrm{~m}$ of Quaternary vertical surface offset, but they also are so extensively modified by erosion that using them to characterize paleoseismic events requires many assumptions and introduces large uncertainties. The high scarps in southern Pahrump Valley may be as old as late Tertiary or early Pleistocene, and are best classified as fault-line scarps rather than fault scarps. No direct evidence was found for partitioning the displacement between dip slip and strike slip. Based on a lack of evidence for Quaternary displacement in a 15- to 20-km-long gap between Stewart and Amargosa Valleys, we conclude that Quaternary activity on the PSV has not been coextensive with deformation on either the AR or AM.

On the basis of a redefinition of the age of faulted surfaces in the Ash Meadows part of the Amargosa Desert, the most recent surface-faulting event on the $A R$ is probably late Pleistocene rather than Holocene as previously reported. Evidence of Quaternary faulting is found along almost $12 \mathrm{~km}$ of the $15-\mathrm{km}$ length of the fault. Most scarps associated with the fault zone are either modified by fluvial erosion or are on erosionally dissected or truncated Tertiary(?) sediment. None were found that are unmodified enough or on suitable sediments to yield reliable scarp-height or surface-offset measurements. Indirect evidence for Quaternary right-lateral slip is suggested by a left step in a previously unmapped strand of the fault. As previously noted, Quaternary activity on the AR appears to have been independent of the PSV.

The EN trends northwest, is steep, and is marked by a 19- $\mathrm{km}$-long set of anastamosing scarps about $2 \mathrm{~km}$ northeast of the northeast base of the Nopah Range. Most of the scarps may have formed in a single surface-faulting event that produced maximum surface offsets of about $1 \mathrm{~m}$. The age of this surface-faulting event is estimated to be late Pleistocene to possibly middle Pleistocene on the basis of soil development, alluvial-fan morphology, and scarp morphology. The late to middle Pleistocene slip rate is no greater than a few hundredths of a mm/yr, and the recurrence time for surface faulting is tens to hundreds of thousands of years. The slip sense is probably oblique (right-lateral normal).

The AM strikes approximately north and has mainly down-to-the-west normal throw. It is located east of and in the footwall of a large-displacement down-to-the-west fault, which forms the eastern margin of the 15-km-wide Amargosa Desert structural trough (Brocher and others, 1993). Quaternary displacement on the $\mathrm{AM}$ is indicated by discontinuous lineaments and a few discontinuous scarps on alluvium. The AM has an estimated length of $40 \mathrm{~km}$, but Quaternary scarps are found only along $10-15 \mathrm{~km}$ of the total length. On the basis of scarp morphology and the estimated ages of offset surfaces, the most recent surface-faulting event is probably late Pleistocene. Surface offsets preserved in sparse scarps are small $(\leq 1 \mathrm{~m})$, and there is 
equivocal evidence of recurrent movement during the late Pleistocene. Using data from the largest scarp, an isolated feature adjacent to Shadow Mountain in the northern Resting Spring Range, the maximum slip rate is estimated at $0.1 \mathrm{~mm} / \mathrm{yr}$, but the small size, discontinuous nature, and subdued morphology of most scarps along the $A M$ suggest a much lower slip rate $(\leq 0.01 \mathrm{~mm} / \mathrm{yr})$ may be possible. Low slip rates are consistent with long-term structural stability indicated by seismic-reflection data (Brocher and others, 1993).

Northeast-trending scarps located in the Amargosa Desert near Amargosa Valley may represent a southwestern extension of the RV. Measured surface offset on the scarps is less than or equal to $1.3 \mathrm{~m}$, and the partitioning of dip slip versus strike slip is not known. The most recent surface faulting event is estimated to be late Pleistocene. Meaningful slip rates and recurrence cannot be calculated. 


\section{REFERENCES}

Anderson, R.E., Bucknam, R.C., Crone, A.J., Haller, K.M., Machette, M.N., Personius, S.F., Barnhard, T.P., Cecil, M.J., and Dart, R.L., 1995, Characterization of Quaternary and suspected Quaternary faults, regional studies, Nevada and California: U.S. Geological Survey Open-File Report 95-599, 56 p.

Birkeland, P.W., 1984, Soils and geomorphology: New York, Oxford University Press, 372 p.

Brocher, T.M., Carr, M.D., Fox, K.F., Jr., and Hart, P.E., 1993, Seismic reflection profiling across Tertiary extensional structures in the eastern Amargosa Desert, southern Nevada, Basin and Range province: Geological Society of America Bulletin, v. 105, p. 30-46.

Bucknam, R.C., and Anderson, R.E., 1979, Estimation of fault-scarp ages from a scarp-height-slope-angle relationship: Geology, v. 7, p. 11-14.

Bucknam, R.C., Crone, A.J., and Machette, M.N., 1989, Characteristics of active faults, in National Earthquake Hazard Reduction Program, Summaries of Technical Reports, v. XXVIII: U.S. Geological Survey Open-File Report 89-453, p. 117.

Burchfiel, B.C., Hamill, G.S., IV, and Wilhelms, D.E., 1983, Structural geology of the Montgomery Mountains and the northern half of the Nopah and Resting Spring Ranges, Nevada and California: Geological Society of America Bulletin, v. 94, p. 1359-1376.

Byers, F.M., Jr., Carr, W.J., Orkild, P.P., Quinlivan, W.D., and Sargent, K.A., 1976, Volcanic suites and related cauldrons of Timber Mountain-Oasis Valley caldera complex, southern Nevada: U.S. Geological Survey Professional Paper 919, $70 \mathrm{p}$.

Carr, W.J., 1984, Regional structural setting of Yucca Mountain, southwestern Nevada, and late Cenozoic rates of tectonic activity in part of the southwestern Great Basin, Nevada and California: U.S. Geological Survey Open-File Report 84-854, 109 p.

1988, Volcano-tectonic setting of Yucca Mountain and Crater Flat, southwestern Nevada, in Carr, M.D., and Yount, J.C., eds., Geologic and hydrologic investigations of a potential nuclear waste disposal site at Yucca Mountain, southern Nevada: U.S. Geological Survey Bulletin 1790, p. 35-49.

Crone, A.J., 1983, Amount of displacement and estimated age of a Holocene surface faulting event, eastern Great Basin, Millard County, Utah, in Crone, A.J., ed., Paleoseismicity along the Wasatch front and adjacent areas, central Utah: Utah Geological and Mineral Survey Special Studies 62, p. 49-55.

Donovan, D.E., 1991, Neotectonics of the southern Amargosa Desert, Nye County, Nevada and Inyo County, California: Reno, Nevada, University of Nevada, unpublished M.S. thesis, map scale 1:48,000, 151 p., 5 pls.

Hanks, T.C., Bucknam, R.C., Lajoie, K.R., and Wallace, R.E., 1984, Modification of wave-cut and faultingcontrolled landforms: Journal of Geophysical Research, v. 89, p. 5771-5790.

Hoffard, J.L., 1991, Quaternary tectonics and basin history of Pahrump and Stewart Valleys, Nevada and California: Reno, University of Nevada, unpublished M.S. thesis, 138 p., 5 pls.

Izett, G.A., and Obradovich, J.D., 1994, ${ }^{40} \mathrm{Ar} /{ }^{39} \mathrm{Ar}$ age constraints for the Jaramillo normal subchron and the Matuyama-Brunhes geomagnetic boundary: Journal of Geophysical Research, v. 99, p. 2925-2934.

MTT Field Geophysics Course, 1985, A geophysical study of Mesquite Valley-Nevada-California border: Journal of Geophysical Research, v. 90, p. 8685-8689. 
Machette, M.N., 1985, Calcic soils of the southwestern United States, in Weide, D.L., ed., Soils and Quaternary geology of the southwestern United States: Geological Society of America Special Paper 203, p. 1-21.

-1989, Slope-morphometric dating, in Forman, S.L., ed., Dating methods applicable to Quaternary geologic studies in the Western United States: Utah Geological and Mineral Survey Miscellaneous Publication 89-7, p. 30-42.

McKittrick, M.A., 1988, Surficial geologic map of the Resting Spring and Nopah Ranges, Inyo County, California, and Nye County, Nevada: U.S. Geological Survey Miscellaneous Field Studies Map MF-1941, 1 sheet, scale 1:62,500.

Morrison, R.B., 1991, Introduction, in Morrison, R.B., ed., Quaternary nonglacial geology-Conterminous U.S.: Boulder, Colorado, Geological Society of America, The Geology of North America, v. K-2, p. 1-12.

Nash, D.B., 1980, Morphologic dating of degraded normal fault scarps: Journal of Geology, v. 88, p. 353-360. Pearthree P.A., and Calvo, S.S., 1987, The Santa Rita fault zone-Evidence for large magnitude earthquakes with very long recurrence intervals, Basin and Range Province of southeastern Arizona: Seismological Society of America Bulletin, v. 77, p. 97-116.

Pezzopane, S.K., 1995, Preliminary table of characteristics of known and suspected Quaternary faults in the Yucca Mountain region: Administrative report to U.S. Geological Survey in cooperation with U.S. Department of Energy, Denver, Colorado, under Interagency Agreement DE-A108-92NV10874, November 1994, $23 \mathrm{p}$.

Piety, L.A., 1994, Compilation of known and suspected Quaternary faults within $100 \mathrm{~km}$ of Yucca Mountain, Nevada and California: U.S. Geological Survey Open-File Report 94-112, 32 p., 2 pl., scale 1:250,000.

Quade, Jay, Mifflin, M.D., Pratt, W.L., McCoy, W.D., and Burckle, Lloyd, 1995, Fossil spring deposits in the southern Great Basin and their implications for changes in water-table levels near Yucca Mountain, Nevada, during Quaternary time: Geological Society of America Bulletin, v. 107, p. 213-230.

Reheis, M.C., and Noller, J.S., 1991, Aerial photographic interpretation of lineaments and faults in late Cenozoic deposits in the eastern part of the Benton Range 1:100,000 quadrangle and the Goldfield, Last Chance Range, Beatty, and Death Valley Junction 1:100,000 quadrangles, Nevada: U.S. Geological Survey Open-File Report 91-41, 9 p., 4 pls., scale 1:100,000.

Reheis, M.C., Sowers, J.M., Taylor, E.M., McFadden, L.D., and Harden, J.W., 1992, Morphology and genesis of carbonate soils on the Kyle Canyon fan, Nevada, U.S.A.: Geoderma, v. 52, p. 303-342.

Sowers, J.M., 1986, Geomorphic map of the Kyle Canyon alluvial fan, Clark County, Nevada: U.S. Geological Survey Open-File Report 86-210, 9 p., 2 pl.

Stewart, J.H., 1988, Tectonics of the Walker Lane belt, western Great Basin-Mesozoic and Cenozoic deformation in a zone of shear, in Ernst, W.G., ed., Metamorphism and crustal evolution of the Western United States, Rubey Volume VII: Englewood Cliffs, New Jersey, Prentice-Hall, Inc., p. 683-713.

Swadley, WC, 1983, Map showing surficial geology of the Lathrop Wells quadrangle, Nye County, Nevada: U.S. Geological Survey Miscellaneous Investigations Series Map I-1361, scale 1:48,000.

Wells, D.L., and Coppersmith, K.J., 1994, New empirical relationships among magnitude, rupture length, rupture width, rupture area, and surface displacement: Seismological Society of America Bulletin, v. 84, p. 974-1002.

Yount, J.C., Shroba, R.R., McMasters, C.R., Huckins, H.E., and Rodriquez, E.A., 1987, Trench logs from a strand of the Rock Valley fault system, Nevada Test Site, Nye County, Nevada: U.S. Geological Survey Miscellaneous Field Studies Map MF-1824, 1 sheet. 
CHARACTERIZATION OF SUSPECTED QUATERNARY FAULTS, AMARGOSA AREA, NEVADA AND CALIFORNIA

APPENDIX A: DEFINITIONS


Profiles of the Rock Valley fault zone (RV)
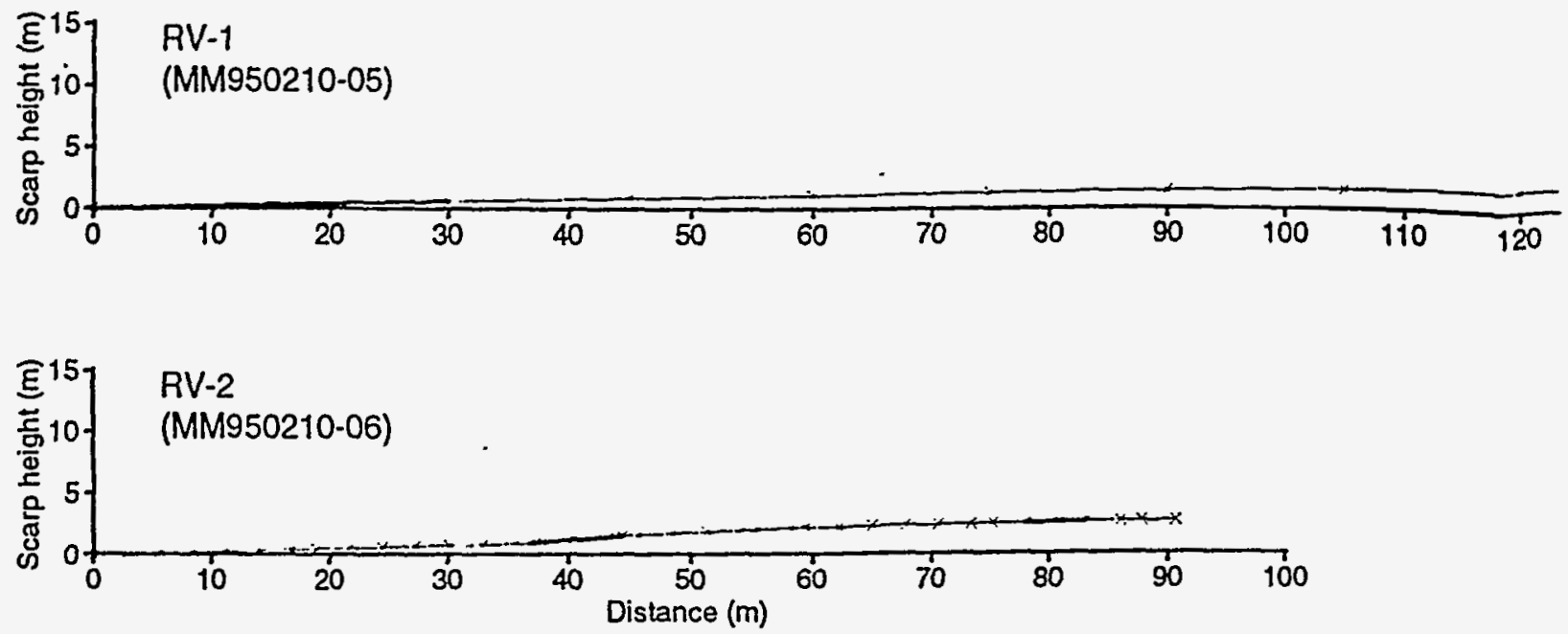


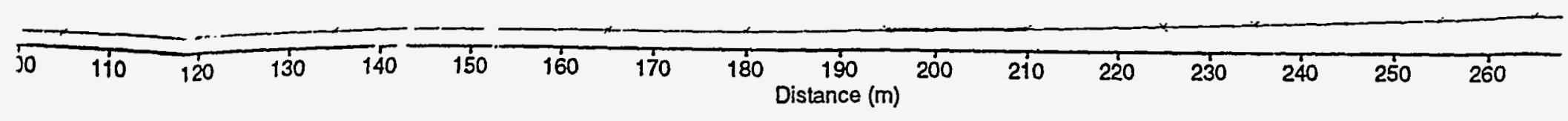

00 


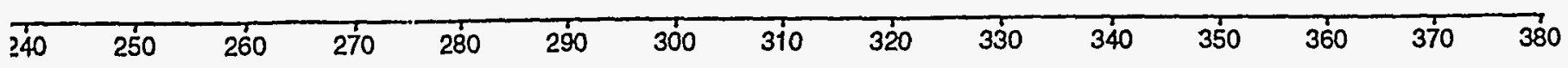


Profile of the Pahrump-Stewart Valley fault zone (PSV)

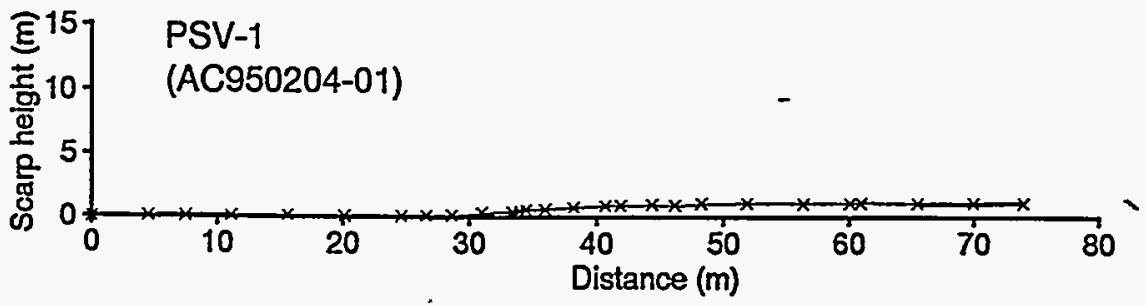

Profile of the Amargosa River fault zone (AR)

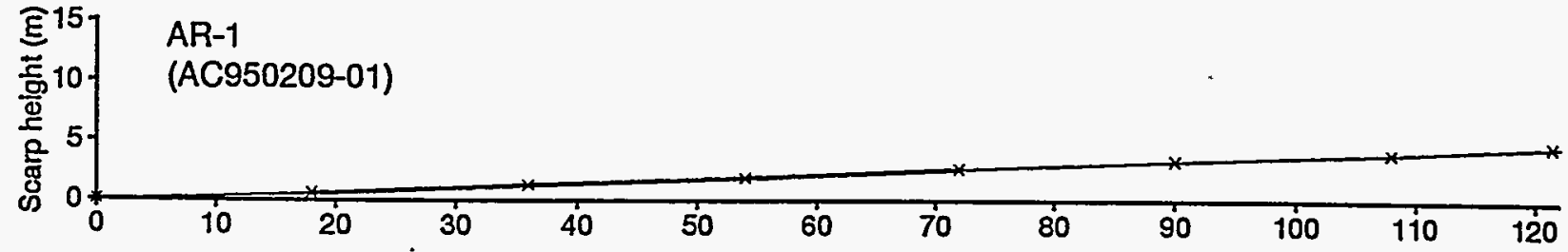

Profiles of the East Nopah fault (EN)
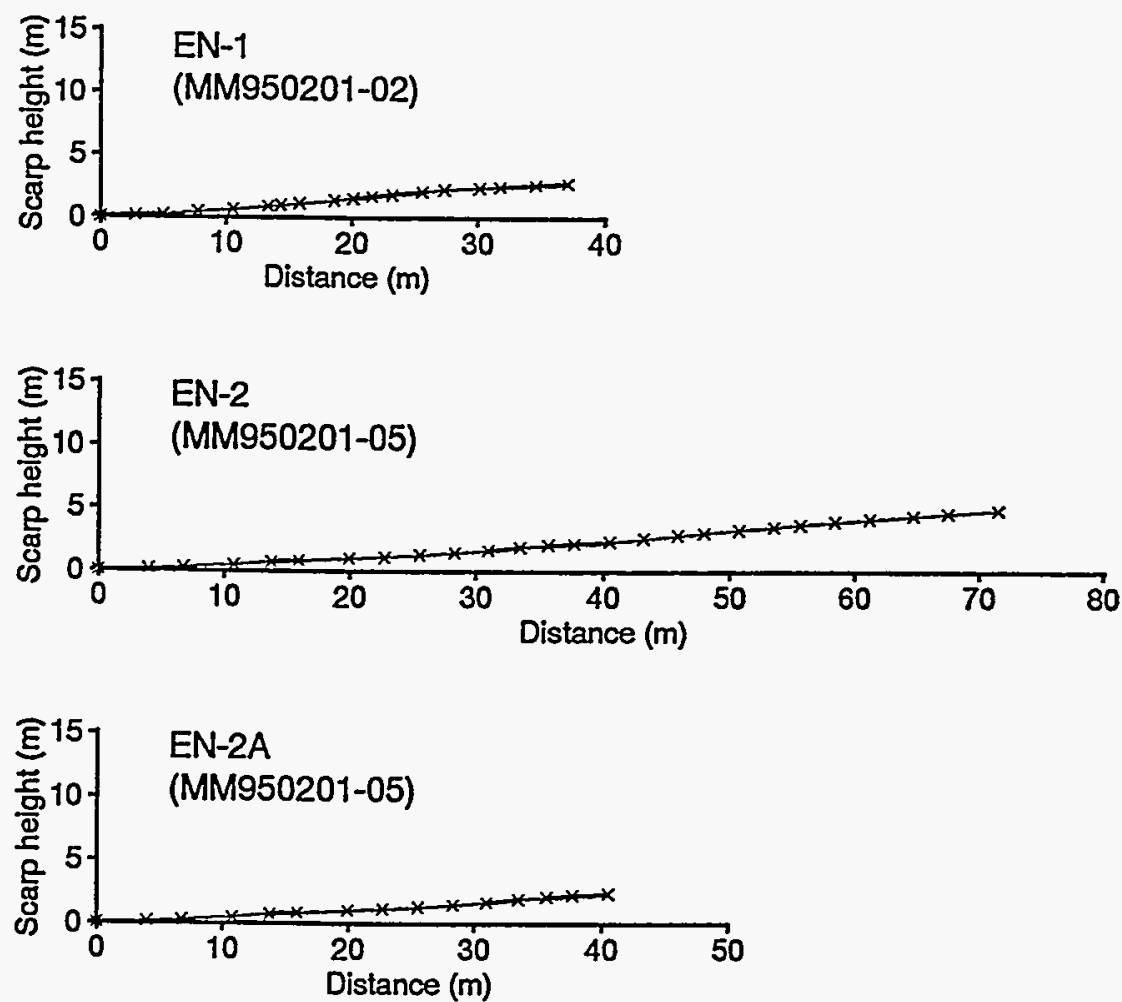


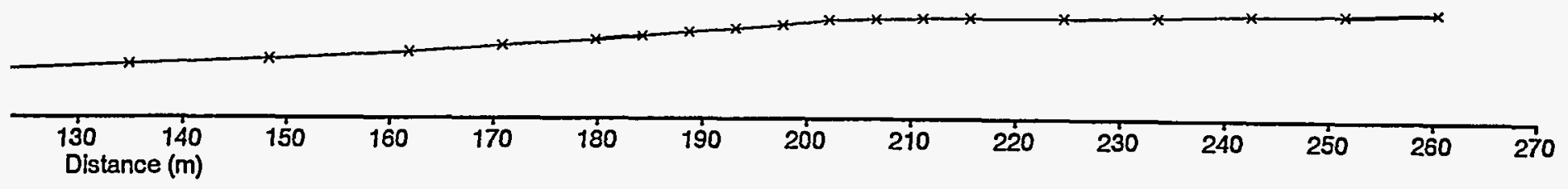


Profiles of the East Nopah fault (EN) continued
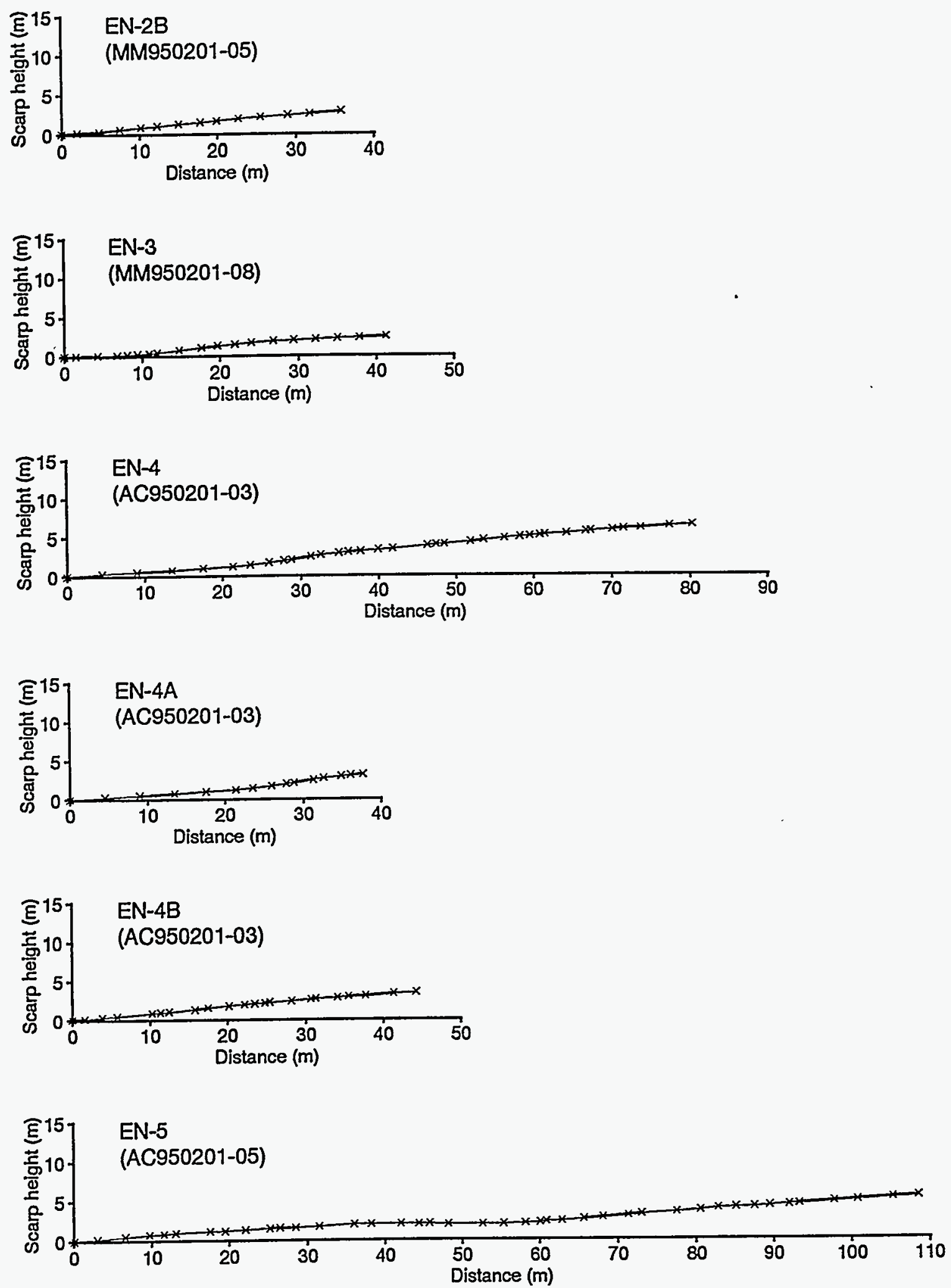
Profiles of the East Nopah fault (EN) contii
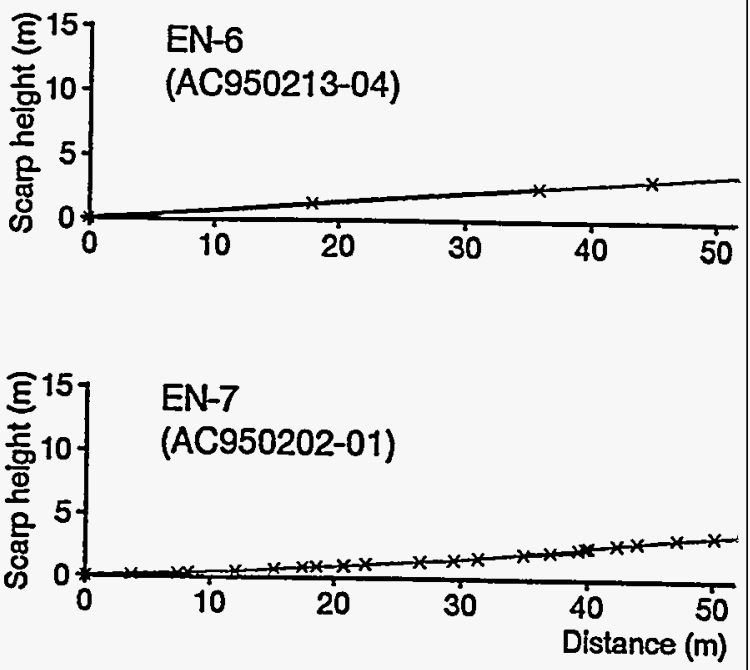

Profiles of the Ash Meadows fault zone ( $A M$
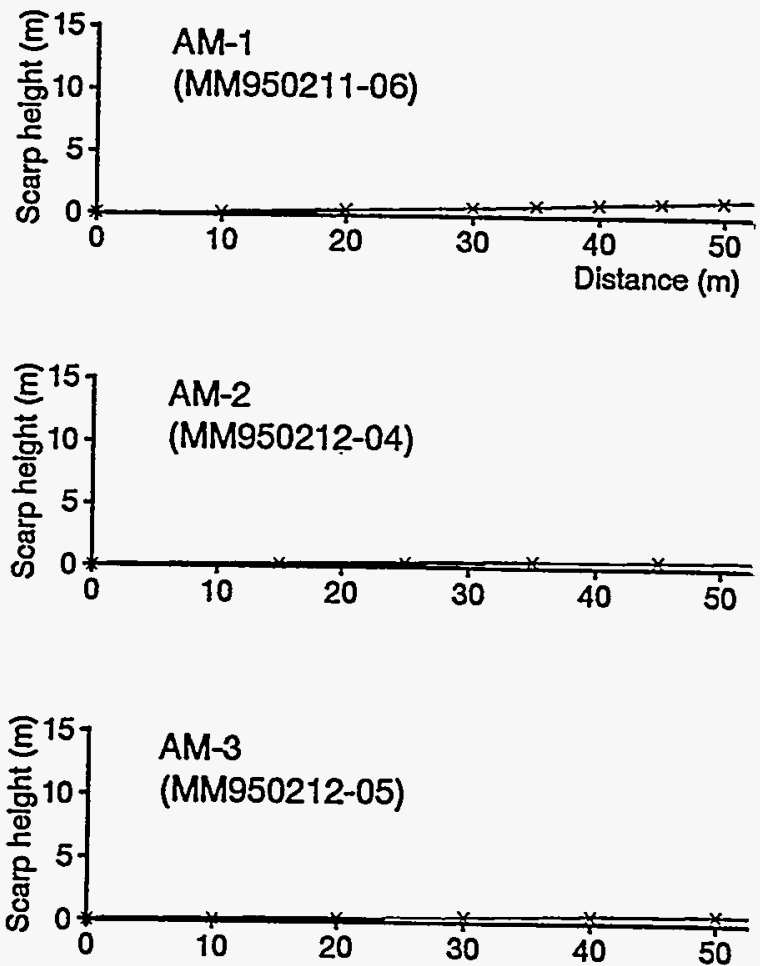

B. 


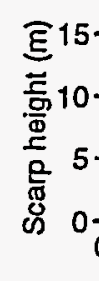

AM-4

(AC950210-04)
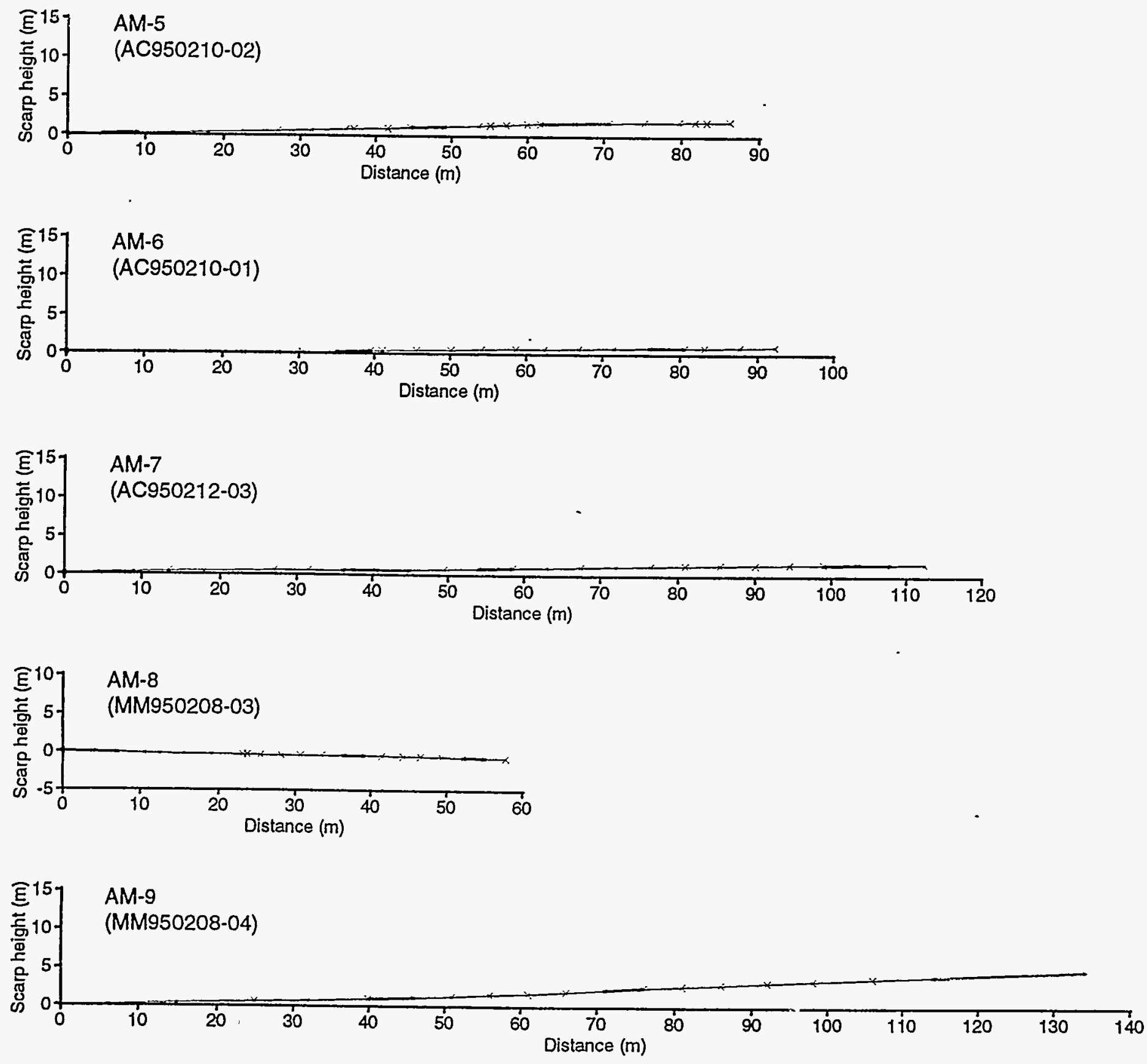


\begin{tabular}{|c|c|c|c|c|c|c|c|c|c|c|c|c|c|c|c|}
\hline $\begin{array}{l}160 \\
\text { ance }(\mathrm{m})\end{array}$ & 170 & 180 & 190 & 200 & 210 & 220 & 230 & 240 & 250 & 260 & 270 & 280 & 290 & 300 & 310 \\
\hline
\end{tabular}



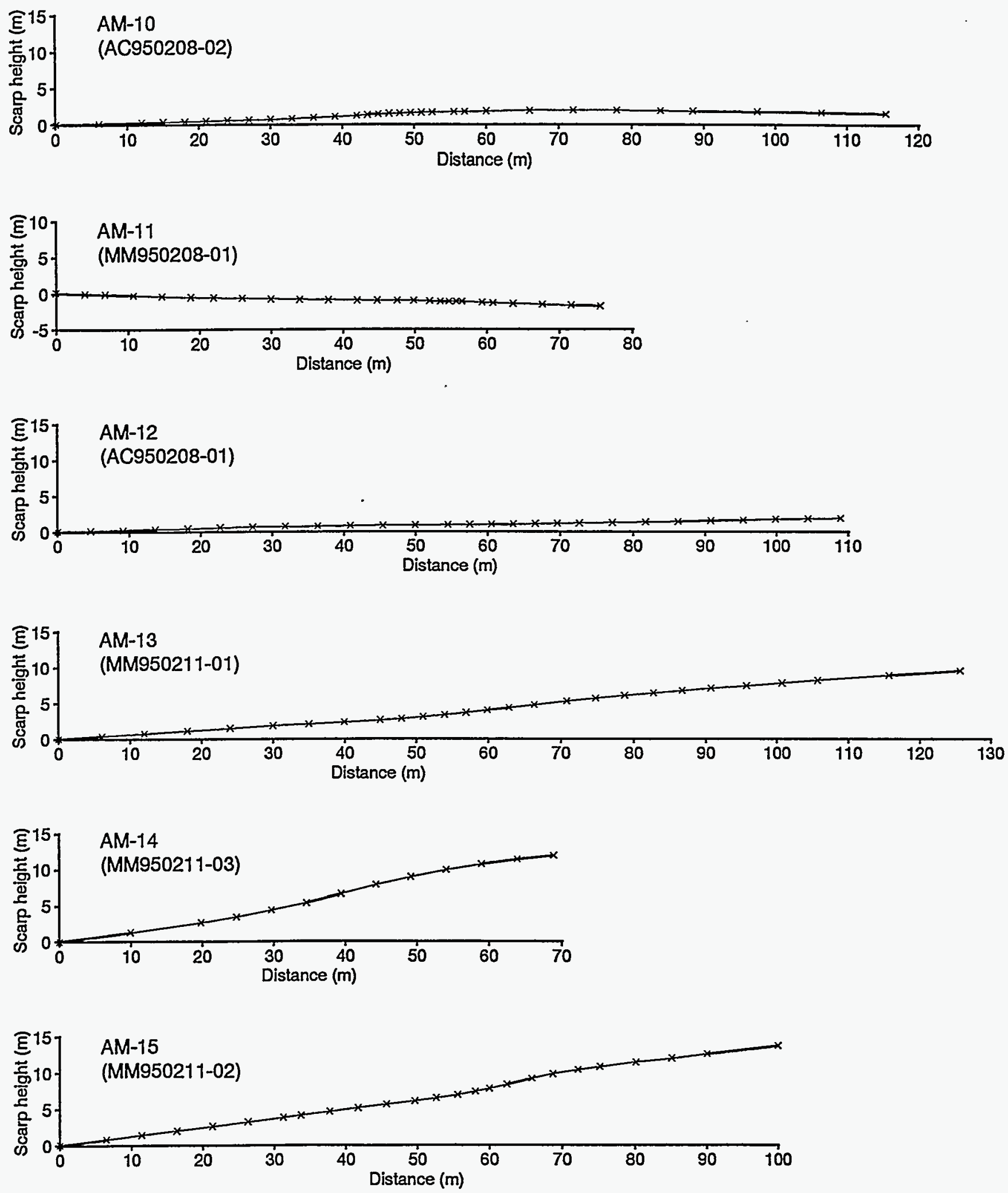